\title{
Effect of Tectonic Structure
}

on the Occurrence of

Ground Water in the Basalt

of the Columbia River Group

of The Dalles Area

Oregon and Washington

U.S. GEOLOGICAL SURVEY PROFESSIONAL PAPER 383-C 
Effect of Tectonic Structure

on the Occurrence of

Ground Water in the Basalt

of the Columbia River Group

of The Dalles Area

Oregon and Washington

By R. C. NEWCOMB

HY D R L OGY OF VOLCANIC-ROCK TERRANES

U.S. GEOLOGICAL SURVEY PROAESSIONAL PAPER 383-C

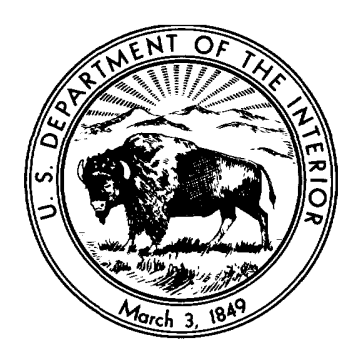

UNITED STATES GOVERNMENT PRINTING OFFICE, WASHINGTON : 1969 


\title{
DEPARTMENT OF THE INTERIOR \\ DONALD PAUL HODEL, Secretary
}

\section{U.S. GEOLOGICAL SURVEY}

\author{
Dallas L. Peck, Director
}

First printing 1969
Second printing 1985

For sale by the Distribution Branch, U.S. Geological Survey 604 South Pickett Street, Alexandria, VA 22304 


\section{CONTENTS}

Abstract

Introduction

Purpose...............

Physiographic setting . . .

Preceding work and schedule for this report........

Well-numbering system

General geologic setting - .

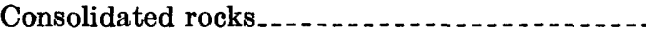

Principal bedrock units. . . . . . . . .

Deformation and early erosion............

Later lavas, deformation, and erosion.....

Unconsolidated rocks........................

Geohydrology of the basalt of the Columbia River Group.

Physical and hydrologic characteristics of the rock -

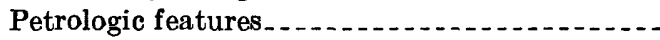

Texture . . .

Layering -...-. -

Joints produced by cooling of the lava..-.

Regional joints...........................

Autobrecciation

Interflow sediments.

Weathering. . .

Folds and faults

Major folds . .

Minor folds

Faults.

Page
C1
1
1
2
3
3
3
3
3
6
6
6
10
10
10
10
10
13
13
14
14
15
15
15
17
18

Geohydrology of the basalt-Con. Page

Ground-water occurrences .................... C20

Tectonic controls on the ground water....... 20

Ease of water entry into the basalt_....- 20

Downdip, a preferential direction of groundwater movement._........... 20

Obstruction of percolation in aquifers _..... 20

Major occurrence, beneath the main water table.

Minor occurrences

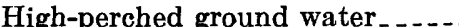

Intermediate-perched ground water

Local examples of structural control of ground

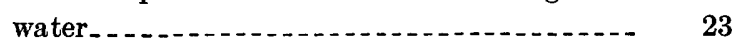

Mosier Creek basin .

Chenoweth Creek basin............. 25

Mill Creek valley

"The Dalles Ground Water Reservoir"-_.- 27

The uplands west of the canyon of the

Deschutes River...... 28

Plateau east of the Deschutes River..... $\quad 29$

Localities north of the Columbia River.-- $\quad 30$

Summary ... . . .

References cited..... 33

\section{ILLUSTRATIONS}

Plate 1. Geologic map of the Dalles area, Oregon and Washington In pocket

\section{Page}

Figdre 1. Maps showing location of the area within the region underlain by the basalt of the Columbia River Group and the location of some principal features of the area...........

2-13. Photographs showing-

2-4. Physiographic, structural, and hydrologic features

5-7. Structural and physiographic features along the Columbia River. -

8-10. Sedimentary formations.
Figdres 2-13. Photographs-Con.

11, 12. Exposures of major tectonic structures crossed by the Columbia River..................... C16,17

13, 14. Erosional and structural characteristics of the basalt in the Deschutes River canyon......

15-18. Sections-

15. Along Mosier Creek

16. Along Mill Creek

17. North-south through The Dalles...-

18. Across Swale Creek valley along the northern part, and northward extension, of section $B-B^{\prime}$ (pl. 1) 



\title{
EFFECT OF TEGTONIC STRUGTURE ON THE OCGURRENGE OF GROUND WATER IN THE BASALT OF THE COLUMBIA RIVER GROUP OF THE DALLES AREA, OREGON AND WASHINGTON
}

\author{
By R. C. Newcoms
}

\begin{abstract}
The 620-square-mile area studied lies across the boundary of the Cascade Range and Columbia Plateaus and affords geologic and hydrologic conditions typical of the basalt region.

The basalt of the Columbia River Group is the oldest rock exposed. More than 2,000 feet of accordantly layered lava underlies the area shown on the White Salmon, The Dalles, and Wishram quadrangle maps, and is at the surface in about half of the area. The overlying Pliocene Dalles Formation remains mostly in the two largest synclines. Its thickness reaches a maximum of about 2,000 feet, but beneath wide areas it is about 500 feet. Post-Dalles lavas and Pleistocene fluvial deposits in places cover the older rocks.
\end{abstract}

The rubibly tops of some of the lava flows and the brecciated flows within the sequence form aquifers that yield large to small amounts of water to wells and springs. The yield of the aquifers depends on the hydrologic conditions and structural situation.

The main tectonic structural features branch from the Cascade Range. They are the Bingen anticline and Columbia Hills anticlinorium and the accompanying Mosier and Dalles synclines. The folds and faults partly control the levels at which ground water occurs.

The natural channel of the Columbia River was graded between low falls and rapids. The Deschutes River is largely graded and the Klickitat River partly graded. The other streams are small and descend to river level through canyoned reaches cut in the basalt; some of the smaller tributaries are cut into or through the Dalles Formation in the broader upland parts of their valleys. Most of the stream valleys follow synclines and are consequent upon the tectonic structures; principal exceptions are at the Bingen and Rowena Gaps where the Columbia River crosses the major anticlines.

Ground water in the basalt aquifers occurs mainly under three situations: (1) beneath the regional, or main, water table near river level, (2) perched at intermediate altitude near baseleveled secondary streams, and (3) perched at high levels near the top of the basalt in the uplands.

Tectonic structure affects ground-water conditions in the basalt by the inclination of the aquifers, by formation of barriers to lateral percolation, by creation of avenues for some vertical movement, and by production of inlets for recharge and outlets for discharge.

The inclination of aquifers increases the opportunity for infiltration and vertical transfer, and also for lateral and vertical percolation along the permeable interflow zones.
The structural barriers to lateral percolation occur where the underlying impermeable strata rise in an anticline, where faults destroy or offset the permeable layers, or where combinations of faults and folds interrupt the aquifers. Together with stratigraphic discontinuities, the structural barriers have caused the impoundment of ground water in the basalt above the main water table. The levels of the outlets around barriers determine the uppermost level to which the obstructed ground water rises.

Ground-water is impounded behind a sheared anticline in Mosier Creek valley, upslope from a fault in Mill Creek valley, and behind a fault across Swale Creek valley. Two other such impoundments of ground water lie behind an anticlinal bulge across three creek valleys near Jap Hollow and isolated by a complex combination of fault and fold barriers that bound "The Dalles Ground Water Reservoir." These impoundments result in ground water occurring at levels many hundreds of feet above the ground-water level in nearby areas of structurally undisturbed basalt.

The discharge of ground water at springs is sufficiently controlled by structural elements that the interpretative process can be reversed; hydrologic features can indicate the geologic structure. For example, in places on long dip slopes, transverse synclines can be indicated by concentrations of springs and transverse courses of streams.

The close relation between the tectonic structure and the occurrence of ground water in the basalt can be used to make better predictions of drilling results. The structural criteria for ground-water storage can be projected elsewhere in the basalt region.

An accurate map of the geology, and particularly of the geologic structures, has been found imperative to the interpretation of the ground-water occurrences.

\section{INTRODUCTION}

\section{PURPOSE}

The narrowing margin between the amount of water we use and the nearly fixed amount of the total natural supply makes necessary more and better information on all facets of our water situation. The ground water and the space in which water could be stored beneath the land surface are partly neglected resources that are available to meet some of our expanding needs for water. 
Preliminary observations on the ground-water characteristics of the widespread basalt of the Columbia River Group (Newcomb, 1959) are tested and refined by closer examination in the present study of a type area. By map and text, this report combines pertinent information on geology and hydrology to determine what we can deduce about the water-storage situations created by the tectonic structures. Among other applications, the lessons learned are to be used in a companion study of the water-storage facilities created by the tectonic structures in the region of 55,000 square miles underlain by the basalt in Washington, Oregon, and Idaho (fig. 1).

\section{PHYSIOGRAPHIC SETTING}

The area lies in the west-central part of the basalt region. It consists of about 620 square miles in a rectangle, 45 minutes of longitude by 15 minutes of latitude, shown on the White Salmon, The Dalles, and Wishram quadrangle maps, scale $1: 62,500$. (See fig. 1 and pl. 1.) The area extends from the Cascade Range
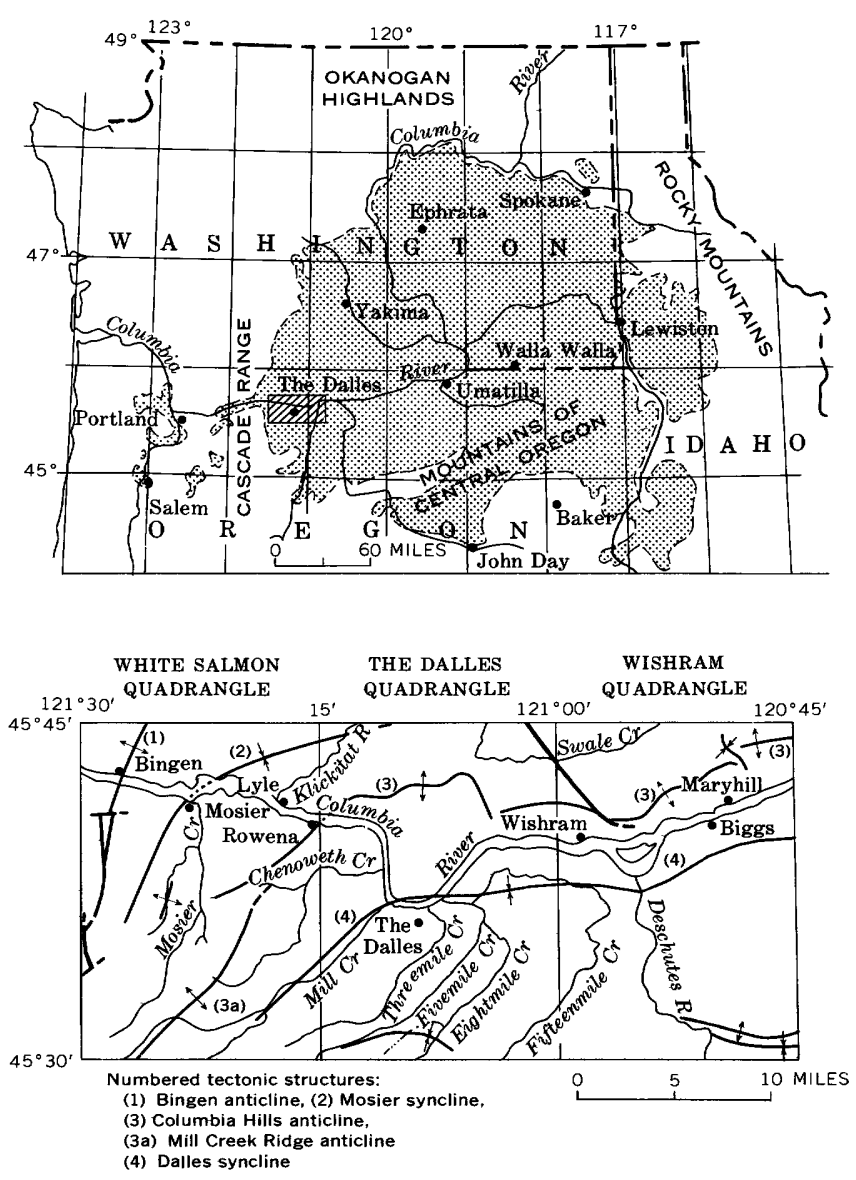

Figure 1.-Location of the area (ruled) within the region underlain by the basalt of the Columbia River Group (stippled) and the location of some principal features of the area. eastward beyond the canyon of the Deschutes River, well out into the Columbia Plateaus physiographic province (Fenneman, 1931). The main topographic feature is the westward-trending gorge of the Columbia River, which transects the area (figs. $3,5,12$ ).

Rock exposures, petrologic characteristics of the basalt, physiography, and climate in the area are representative of the whole region (Newcomb, 1959, pl. 1) underlain by the basalt of the Columbia River Group, but the tectonic deformation is a little greater than average.

The area includes a great variety of physiographic features and tectonic structures. Landforms range from level, gently rolling plateaus to steep canyons and mountains. The degree of deformation ranges from none to that resulting in overturned and crushed basalt. The cover mantling the basalt varies in thickness and character from none through shallow and deep soil to sedimentary and volcanic deposits which in places are many hundreds of feet thick.

The climate ranges from humid in the highest parts at the west side of the area, where 35-40 inches of precipitation falls annually, to semiarid in the lowest altitudes at the east side, where only $8-10$ inches is received.

In a large sense, the area is plateau greatly diversified by broad extensive slopes and low mountain ranges, and subdivided by gorges and canyons. Much of the southern half consists of separate parts of one plateau that slopes northward to the east-west ridge known as the Columbia Hills. Where this plateau once intersected the toe of the Columbia Hills uplift, the Columbia River entrenched a canyon that is 800 feet deep east of Rowena Gap. The Deschutes River, in a youthful canyon (fig. 14), flows down the slope of that plateau.

The physiography of the western part of the area is dominated by broad ridges and valleys which are part of the Cascade Range. These include the ridge called Sevenmile Hill in Oregon and the Columbia Hills in Washington, the Hood River Mountain-Burdoin Mountain ridge, and the intervening lowland in which the Klickitat River and Mosier Creek enter the Columbia River. The deepest segments of the river canyons, known as Rowena and Bingen Gaps, have been cut by the Columbia River through the two ridges mentioned above. (See figs. 2, 11.) Starting at Rowena Gap, the river's canyon through the Cascade Range is known by the term the "Columbia Gorge."

The natural channel of the Columbia River was largely graded between widely separated falls and rapids, where the deepest of its multiple channels were irregularly entrenched along joint and other fracture planes in the descent over the edge of particularly mas- 
sive layers of the basalt. The falls at Celilo, where the total descent was about 50 feet, were the greatest of the falls. These falls are now submerged in the reservoir behind the Dalles Dam. The Deschutes River (fig. 14) is largely graded to the Columbia River level, but the Klickitat River is only partly graded; it descends in places over the more coarsely jointed layers of basalt in narrow channels entrenched along joint planes (fig. 4).

In addition to the major physiographic units, important minor elements include an edge of the Hood River Valley in the Cascade Range at the west side and most of Swale Creek Valley in the part of the Columbia Plateaus lying to the north of the Columbia Hills.

\section{PRECEDING WORK AND SCHEDULE FOR THIS REPORT}

Previous work on geology and hydrology in the area consists largely of that described in a water-supply paper by A. M. Piper (1932). A map of the locality of the Dalles Dam was available from Sargent's (1956) work. The McDermid Cone had been shown to be a Quaternary volcanic vent, and the young lava near Haystack Butte had been mentioned by Hodge $(1932 ; 1942$, p. 29-30).

The fall of 1962, the summer and fall of 1963, and the first half of 1964 were spent in fieldwork and drafting of the map and illustrations. Most of the groundwater data were contributed by well drillers, and other data were collected by the office of the Oregon State Engineer, the Water Resources Division of the Washington Department of Conservation, and the district offices of the Water Resources Division of the U.S. Geological Survey.

\section{WELL-NUMBERING SYSTEM}

The wells used for reference data in this report are numbered according to the rectangular system of land division. The first two numbers of the full well symbol refer to the township and range, the third denotes the section and is followed by a letter that indicates the 40 -acre tract. The one-sixteenth tracts are lettered alternately and successively westward and eastward in horizontal tiers starting with $\mathrm{A}$ in the $\mathrm{NE} 1 / 4 \mathrm{NE} 1 / 4$ and ending with $\mathrm{R}$ in the southeast corner; the letters $\mathrm{I}$ and $\mathrm{O}$ are omitted. The last figure is a serial number of the wells in that 40-acre tract. Thus, well $1 \mathrm{~N} / 12-28 \mathrm{Q} 1$ is the first well recorded in the SW1/4 $\mathrm{SE}^{1 / 4}$ sec. $28, \mathrm{~T} .1 \mathrm{~N}$., R. $12 \mathrm{E}$. The full well number is used in a few places for full clarity; the post-hyphen part giving the section, tract, and serial number, such as $30 \mathrm{~N} 1$, is used generally in the text; only the letter and serial number are given on the map.

\section{GENERAL GEOLOGIC SETTING}

\author{
CONSOLIDATED ROCKS
}

PRINCIPAL BEDROCK UNITS

The thick sequence of accordantly layered lava flows of Miocene and Pliocene age is the oldest rock exposed and comprises the main bedrock of the area. (pl. 1). This unit in its entirety is shown as the basalt of the Columbia River Group. The total thickness of the rock unit exceeds the 2,000 feet of layered strata exposed in Rowena and Bingen Gaps. Much of the top thousand feet of it is well exposed in many places along the Columbia River (figs. $3,5,7)$. This thick sequence of lava rock is the main water-bearing unit of the area.

Overlying the basalt is a thin to thick deposit of fragmental volcanic debris and sedimentary materials, called the Dalles Formation. The deposition of the Dalles Formation started with little time delay after the end of the basalt outflows. The age determinations on the Dalles Formation have generally agreed with the early Pliocene age first assigned by Buwalda and Moore (1930), but extensions of the sedimentary facies toward slightly younger deposits on the east indicate that part of the sedimentary facies may have been deposited as late as the middle Pliocene (Newcomb, 1966).

The formation consists of two facies-a volcanic-sedimentary deposit of effusive debris and a sedimentary deposit. One facies is centered in a former fan of waterlaid and airborne grayish-tan volcanic debris from sources to the southwest. The other facies comprises the remnants of a sedimentary train that was laid down to the east and around the north edge of the debris fan. The two facies interfinger in a broad zone which follows the lower part of Fifteenmile Creek and passes near The Dalles. Locally, the formation is known by such common terms as "sandstone," "chalk," or "conglomerate." Its total stratigraphic thickness is about 1,800 feet near Upper Mill Creek in the southwest part of the area, where the formation is all fragmentary debris of volcanic origin. The total thickness decreases to the east and north; it is about 450 feet near the Deschutes River and about 160 feet at the east edge of the area, where only the sedimentary facies is present. On the north side of the Columbia River, the thickness exceeds a hundred feet in only a few places, and the formation consists largely of the sedimentary deposit.

The diameter of the particles in the volcanic effusive deposit decreases to the east and north, as does also the percentage of the included andesite clasts (fig. 8). Eastward from Fifteenmile Creek, the sedimentary deposit predominates and layers of water-laid pebble and cobble conglomerate become a progressively larger part of the 


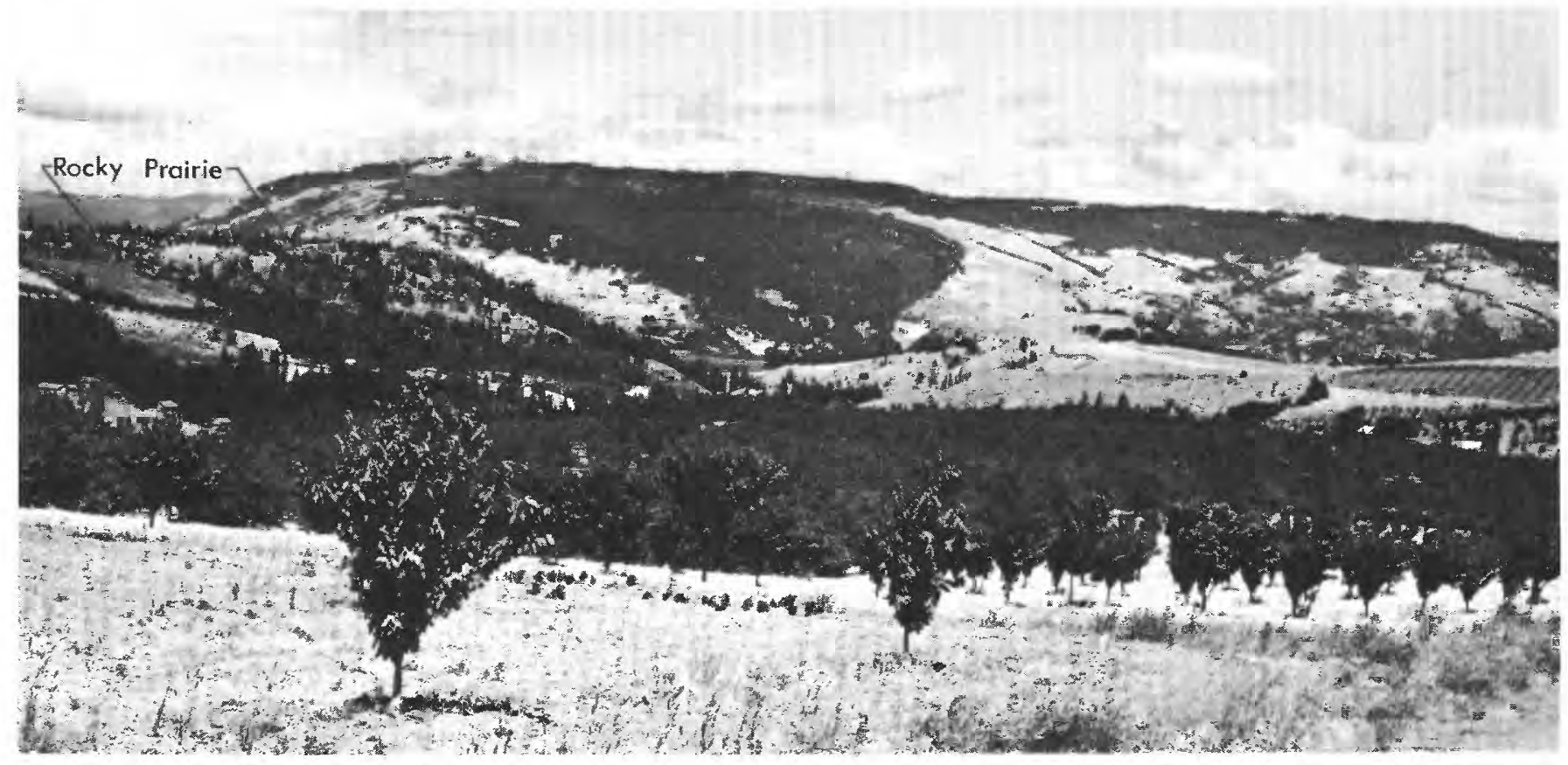

Frgure 2,-View north down the lower part of the Mosier Creek valley, domed form of Bingen anticline making Burdoin Mountain in the background. Axis of the narrow Rocky Prairie anticline continues east across center ground. The orchards in the middle ground are mostly on Quaternary lakebeds within the Orchard syncline. The foreground is an erosional slope on the Dalles Formation.

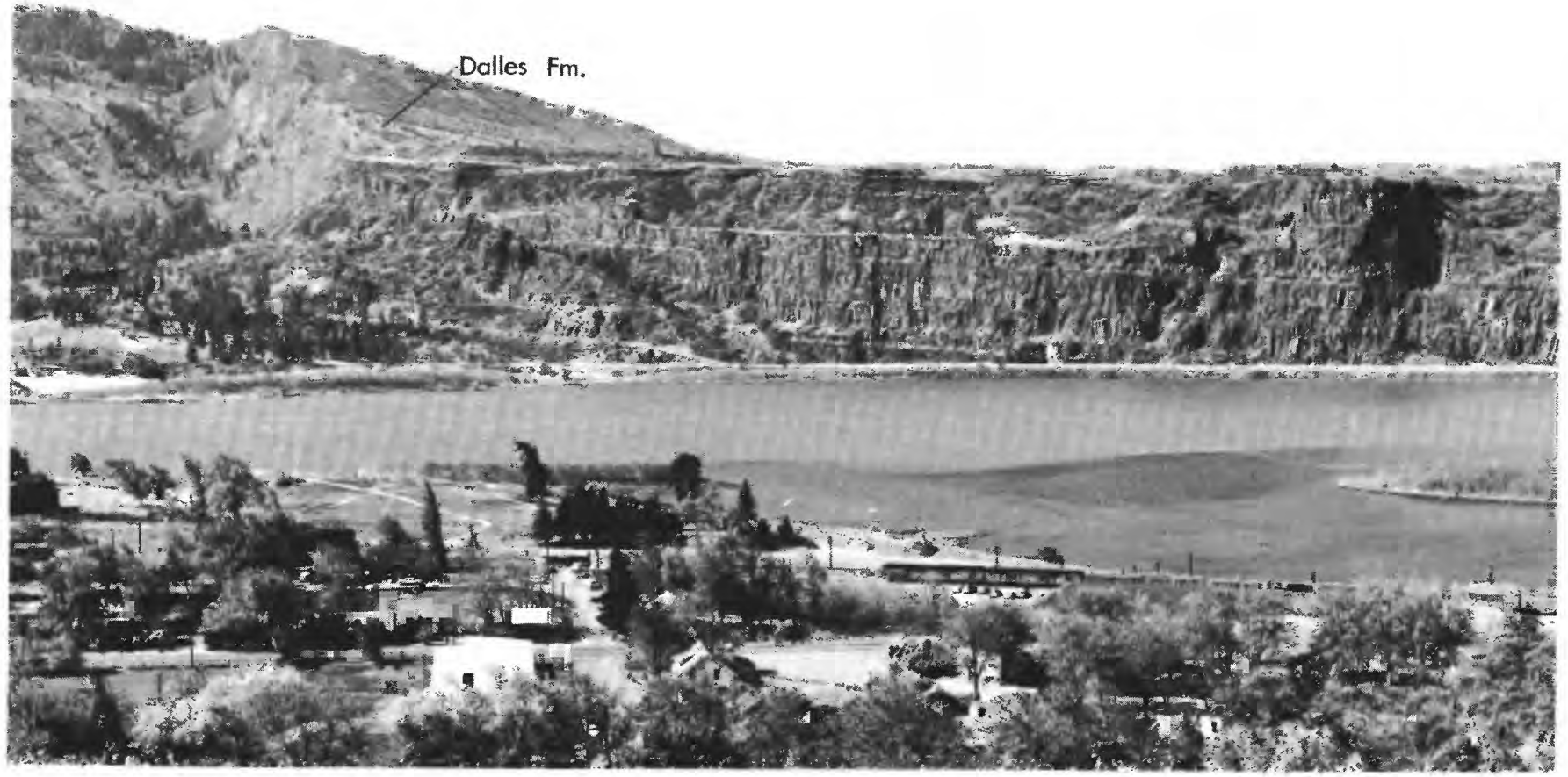

Figure 3.-View southwest from Lyle across the river toward basalt escarpment of Rowena Point. Sharp upturn of the strata in left background is part of Ortley segment of Columbia Hills anticline and its westward branch to the Rocky Prairle anticline. 


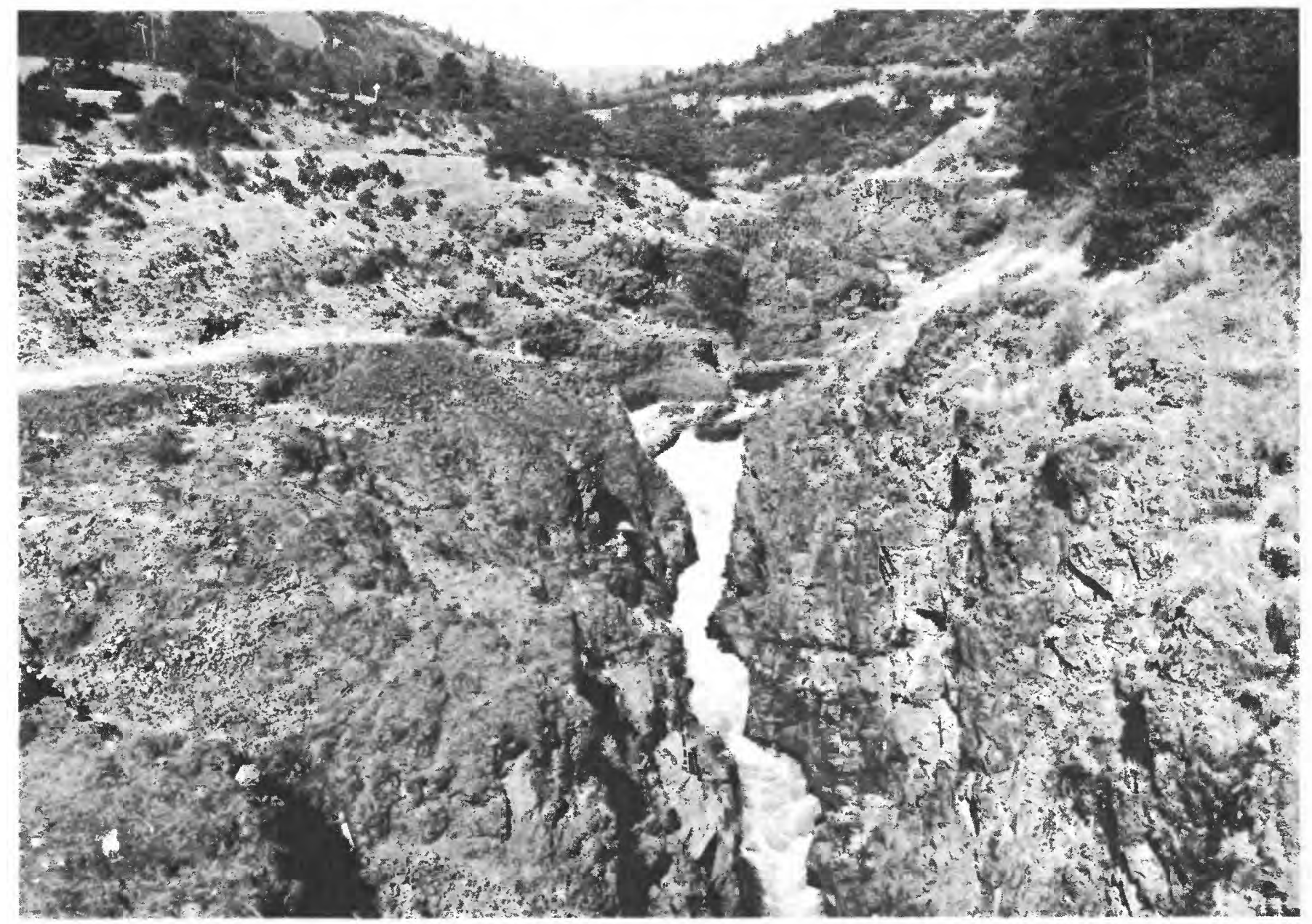

Figure 4.- Vlew northward up the Klickitat River canyon in the narrow dell being cut through a particularly massive basalt flow just above the mouth of Silvies Creek ( $\mathrm{SE} 1 / 4$ sec. 26, T. 3 N., R. 12 E.). Some concrete flumes along the river assist migratory flsh around the most difficult of the rapids.

deposit. This conglomerate forms about half the 100 to 200 -foot thickness of the formation east of the Deschutes River. The conglomerates consist mostly of westward- and northwestward-transported stream-rounded pebbles and cobbles of dense andesitic and basaltic rocks, silicified volcanic rocks, and basalt similar to the basalt of the Columbia River Group. No quartzite or metamorphics of the type common to the northern Rocky Mountain region were seen in the conglomerates.

One 50-foot-thick flow of basaltic lava occurs within the formation and forms an erosion-retarding rim around the upland between Fifteenmile Creek valley and the adjacent river canyons.

As described by Piper (1932, p. 125), the erosional relief on the basalt beneath the Dalles Formation is small and, at most places, the basal beds of the Dalles Formation are parallel to the top flows of the basalt.
This conformity can be observed in the lower part of Chenoweth Creek valley northwest of The Dalles, on Mill Creek Ridge, on Hood River Mountain, in a highway cut 3 miles northwest of Lyle, and in many other places. However, in a few places, small angular discordance is present and erosional unconformities exist. Drilling records also indicate that erosional unconformities occur at places. The top of the basalt is slightly weathered beneath the Dalles Formation in exposures near the mouth of Badger Creek in the lower Chenoweth Creek valley and in the west side of Signal Hill east of The Dalles, but the top of the hard and resistant basalt in ravines 3 miles west of Lyle is fresh and unaltered.

Overlying the Dalles Formation and the basalt of the Columbia River Group southeast of Hood River is a basalt porphyry which dips west into the Hood River 
Valley along the flank of Bingen anticline, where it seems to have sustained at least part of the deformation of the post-Dalles folding. A different basalt porphyry caps the Dalles Formation in the Balch Lake area northwest of Lyle, where its single flow has been warped in the Mosier syncline.

\section{DEFORMATTON AND EARLY EROSION}

Minor deformations were beginning during late Miocene or early Pliocene time, and major deformations occurred in middle or late Pliocene and in early or middle Pleistocene time.

Some mild warpings were taking place while the top part of the basalt of the Columbia River Group was being extruded. Evidences of these mild deformations are: (1) the many layers of pillow lava, which indicate frequent ponding of drainage, in the uppermost 500 feet of the basalt in the Dalles syncline; (2) the lack of eastward extension of the thick flows at the top of the basalt in the Mosier area, which shows that an ancestral high on the east may have limited the top flows; and (3) an apparent pre-Dalles(?) age of a fault in the Mill Creek valley (fig. 16).

After the deposition of the Dalles Formation, extensive warping took place along the lines of the present major structures. Erosion had beveled strata of the Dalles Formation (pl. 1) to form the "Mount Hood Flat erosion surface," which Piper (1932, p. 141) tentatively correlated with Buwalda's (1929) early or middle Pliocene "Ochoco erosion surface," before the deposition of the volcanic rocks of High Cascades started in late(?) Pliocene time.

\section{LATER LAVAS, DEFORMATION, AND EROSION}

Part of the erosion surface preserved in Mount Hood Flat, which is centered 5 miles southwest of The Dalles, was covered by flows of olivine-bearing andesitic basalt. It is the type of rock mapped as "volcanic rocks of High Cascades" by Callaghan and Buddington (1938, pl. 1) and commonly called the "Cascade lava." The outflow of lava of this group took place over a relatively long time, in late(?) Pliocene, Pleistocene, and Recent time. The lava extrusions continued long enough that some postdated the large uplifts of middle Pleistocene and even some of the following erosion; late lavas moved down canyons which had been cut several hundred feet below the Mount Hood Flat erosion surface.

The olivine-bearing basalt of the intracanyon lavas at White Salmon is probably the youngest large extru- sion of the Cascade-lava epoch in this area. Farther east, the smaller extrusions of lava and effusive materials at McDermid Cone and Haystack Butte (fig. 7) belong to the prominent area of "Simcoe lava" north of this map area and appear to be as young as the lavas near White Salmon.

A second major deformation resulting in regional uplift started in early or middle Pleistocene time; the rocks that were deformed included the early parts of the volcanic rocks of High Cascades. The regional uplift set the conditions for the erosion of the great canyons and gorges. This deformation and uplift may have occurred in several stages, but the large river canyons had been cut virtually to their present form by late Pleistocene time, when melt water from the Wisconsin (Flint, 1937, p. 222) continental glacier flowed down the Columbia River. (See figs. 5-7.)

\section{UNCONSOLIDATED ROCKS}

Unconsolidated sedimentary deposits of Tertiary (?) and Quaternary age include gravel, sand, and silt laid down by the Columbia River when it flowed at its present general level, but also when, at times, it was swollen by glacial melt water and when it was impounded to great depth during the last of the glacial stages of Pleistocene time. Glaciofluvial gravel occurs mainly on rock benches below altitudes of 600 feet, but some lies at higher levels, where currents along the shores reworked local materials, presumably during the Lake Lewis episode. (See fig. 9.) Deposits of silt, sand, and clay are preserved mostly in protected side valleys, where they were laid down in proglacial Lake Lewis. The dam which could have impounded such a lake was thought by Russell (1893, p. 25-29) to have been caused by a mountain glacier; Allison (1933, p. 719) reported the evidence indicated that the dam was due to ice jams, lava, or landslides and that the dam started accumulating in the gorge west of Hood River, which is just west of this area.

Fine-grained lacustrine deposits underlie the valley plain in places as high as altitudes of 800 feet in the Hood River Valley, where they are among the materials grouped as undifferentiated alluvium, and to about 820 feet in Mosier Creek valley. They are of little significance in Mill Creek valley, where they occur as high as about 600 feet. In the eastern part of the area they may have been extensively removed or reworked by the wind. The former existence of proglacial Lake Lewis is indicated by erratics, shorelines (fig. 7), and lakebed deposits, all of which have been extensively described 


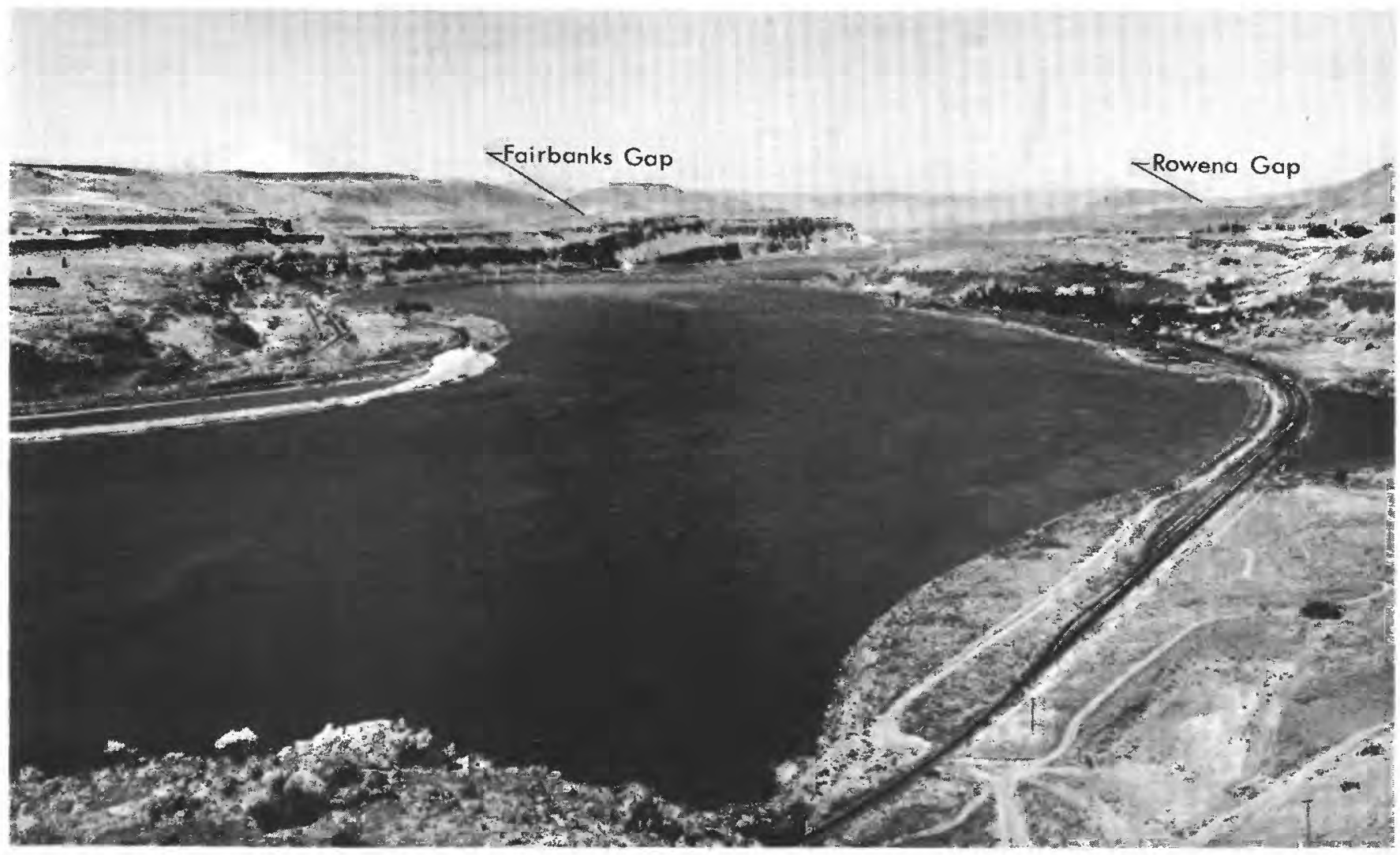

Figure 5.-View west down the Columbia River over Wishram (in trees on right bank) and the Celilo Bridge. A mile-long ramp of basalt dips $2^{\circ}$ upstream from Fairbanks Gap. The rimrock at the top of the south side of the gorge is formed by the porphyritic basalt flow in the Dalles Formation. The top of the basalt of the Columbia River Group is about 50 feet above the floor of Fairbanks Gap.

for southern Washington and north-central Oregon (Allison, 1933). Allison's general maximum level of 1,150 feet for the occurrence of erratics farther east is $50-150$ feet higher than the maximum level to which the writer found similar features in this area. The locations of a few of the large granitic erratics observed by the writer at altitudes above 800 feet are shown on plate 1 .

The depositional and erosional features leit by the proglacial Lake Lewis have had an outstanding effect on the economic potential of the area. Soil and overburden were scoured from the slopes along the Columbia River to a general altitude of a thousand feet at The Dalles. Gaps into side valleys, like those to Fifteenmile Creek near Fairbanks and Petersburg, were occupied by flowing water and later abandoned to the wind. Landslides were induced in blocks of unstable ground wetted by the high levels of the impounded water. Lacustrine and alluvial deposits were laid down to become important soil-forming materials in the side valleys or to be redeposited as loess on the adjacent hills, and gravelly deposits were left where they now form sources of construction material.
In the Deschutes River canyon, the silty soils resulting from the Quaternary lakebeds form a particular type called Sagemoor (Mayers, 1964). This name is generally assigned to soils formed from silty deposits in this proglacial lake in the Columbia, Umatilla, Yakima, and Walla Walla river basins farther upstream.

Loess soil becomes progressively more common and thick eastward from the general longitude of The Dalles. East of the Deschutes River, it is the general soil of the uplands. The loess consists of clayey silt which was deposited in two or more episodes. It may have a maximum thickness as great as 20 feet in places north of Gordon ridge. In this work, the loess was not mapped because it had little direct bearing on the ground-water occurrences. Because of this loess cover, it is difficult to discern the underlying bedrocks in some places in the southeastern part of the area.

Along with the foregoing, the alluvial and colluvial (fig. 10) materials complete the roster of the geologic materials that underlie the area. The rest of the report concerns the main bedrock unit, the basalt of the Columbia River Group. 


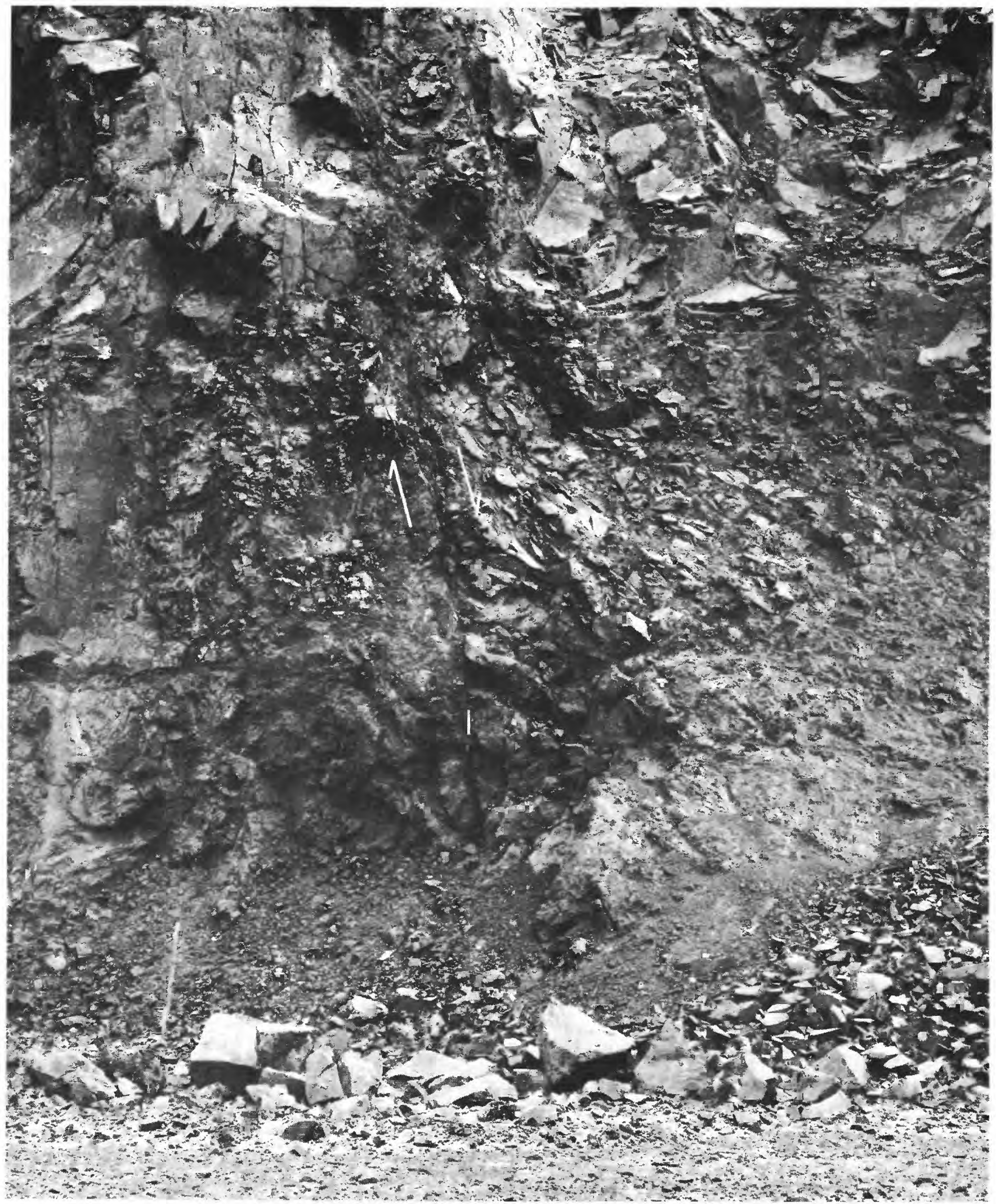

Figdre 6. - Fault exposed by roadcut along left bank of Columbia River 0.85 mile west of Cellio Bridge. This small displacement and fracture zone is the east end of the east-dipping basalt shown in photograph (fig. 5) just above. Movement and breakage here is insufficient to stop lateral movement of ground water. Hand pick on fault below center of photograph is 14 inches long. Vertical displacement is down about 4 feet on right (west) side, per arrows. 


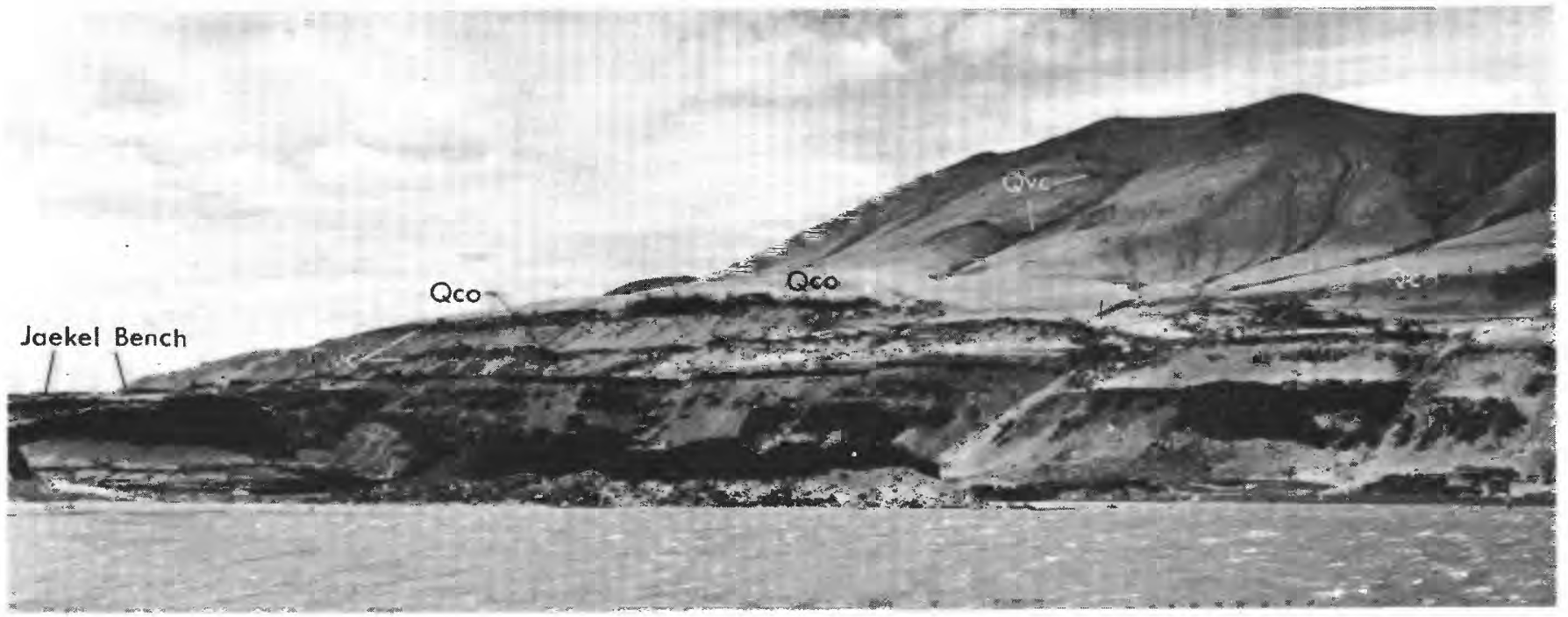

Figure 7.-View northwest across the Columbia River to Haystack Butte and Jaekel Bench. The east end of Miller Island is in the foreground. Quaternary lava $\left(Q_{\mathrm{vc}}\right)$ overlies part of the colluvium $\left(\mathrm{Qco}_{\mathrm{co}}\right.$. Part of a shoreline notch of proglacial Lake Lewis is visible in the colluvium at the extreme right center near 1,100 feet altitude.

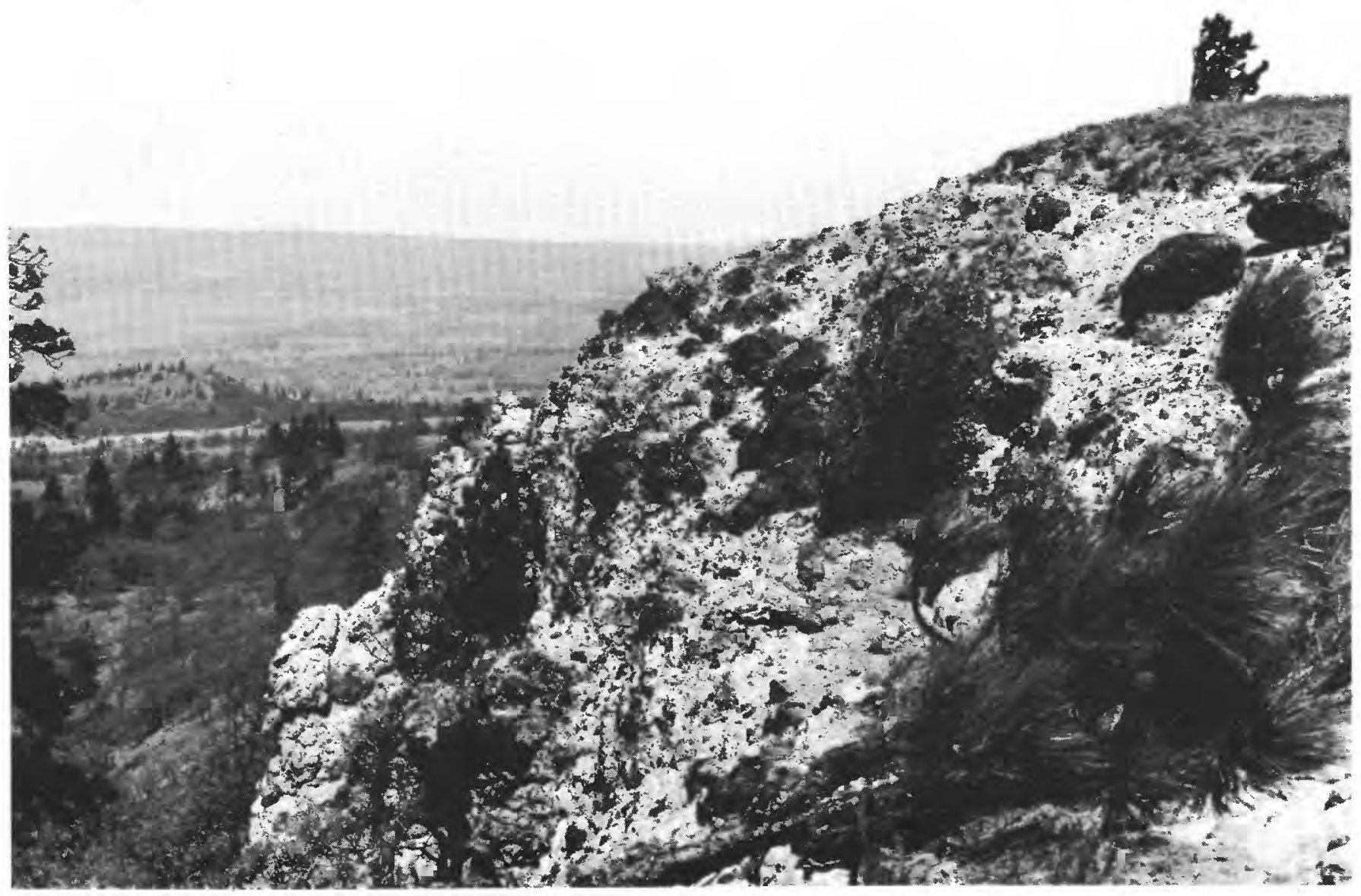

Figure 8.-Agglomerate of the Dalles Formation in erosional escarpment 3 miles southeast of Mosier (SE1/4 sec. 8, T. 2 N., R. 12 E.). Rounded andesite boulders, both scattered and in rude layers, comprise 10-60 percent of the agglomerate. They form typical residual litter on erosinoal surfaces of this debris-flow type of deposit. 


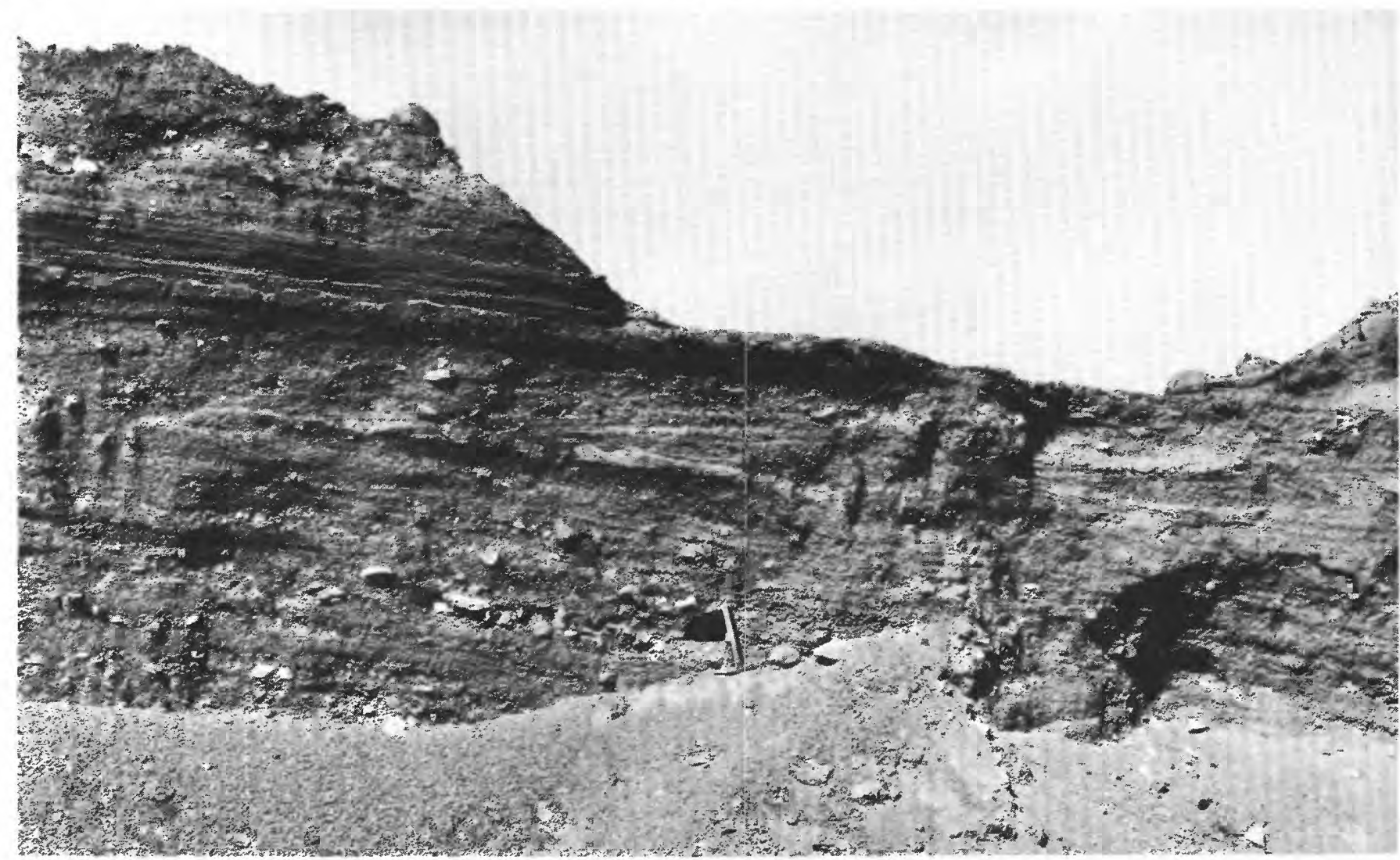

FTGURE 9.-Glaciofluvial gravels remaining on slope west of Flfteenmile Criek 4 miles northeast of The Dalles (SE1/4 sec. 28 , T. 2 N., R. 14 E.).

\section{GEOHYDROLOGY OF THE BASALT OF THE COLUMBIA RIVER GROUP}

\section{PHYSICAL AND HYDROLOGIC CHARACTERISTICS OF THE ROCK}

\section{PETROLOGIC FEATURES}

TEXTURE

The basalt is a black to dark-gray dense fine-grained and even-textured rock composed mostly of microscopic crystals with some intercrystalline glassy groundmass. An average basalt of this sequence has a nonporphyritic microgranular texture and is composed of labradorite $\left(A n_{50-55}\right), 55$ percent; augite (identified commonly as pigeonite by Campbell, 1950), 15 percent; magnetite, 5 percent; and brown glass and tiny microlites, 25 percent. As much as 10 percent olivine may be present in places in some flows. Some of the flows contain scattered lightgray labradorite phenocrysts that are as much as onefourth of an inch long. Crystals or globules of crystals of olivine or augite as much as one-eighth of an inch in diameter are visible in some of the basalt. Most of the rock has an even microgranular texture, but in a few places the crystals are so minute that the basalt has a flinty or near-glassy texture.

The mineral grains of the average basalt and the interstitial brown glass are dispersed evenly without directional orientation. The lack of directed alinements of crystals and the absence of abrasion of delicate crystals within the basalt, which have been observed by most petrographers, is interpreted to indicate that most of the crystallization, at least the main part of the plagioclase, occurred after the highly fluid lava had come to rest. Such a postflow age for the crystallization is suggested also by the general lack of crystals in the glassy phases of the basalt, the chilled margins, and the lapilli of intercalated lapilli tuff.

\section{LAYERING}

The most distinctive petrologic structures are layering and jointing. The layering resulted from the accumulation of the basalt as successive flows of highly fluid lava of the same general chemical and mineralogical type. The thickness of the major layers (the flows) ranges generally from 5 to about 200 feet and averages about 80 feet. Flows are nearly everywhere distinct 


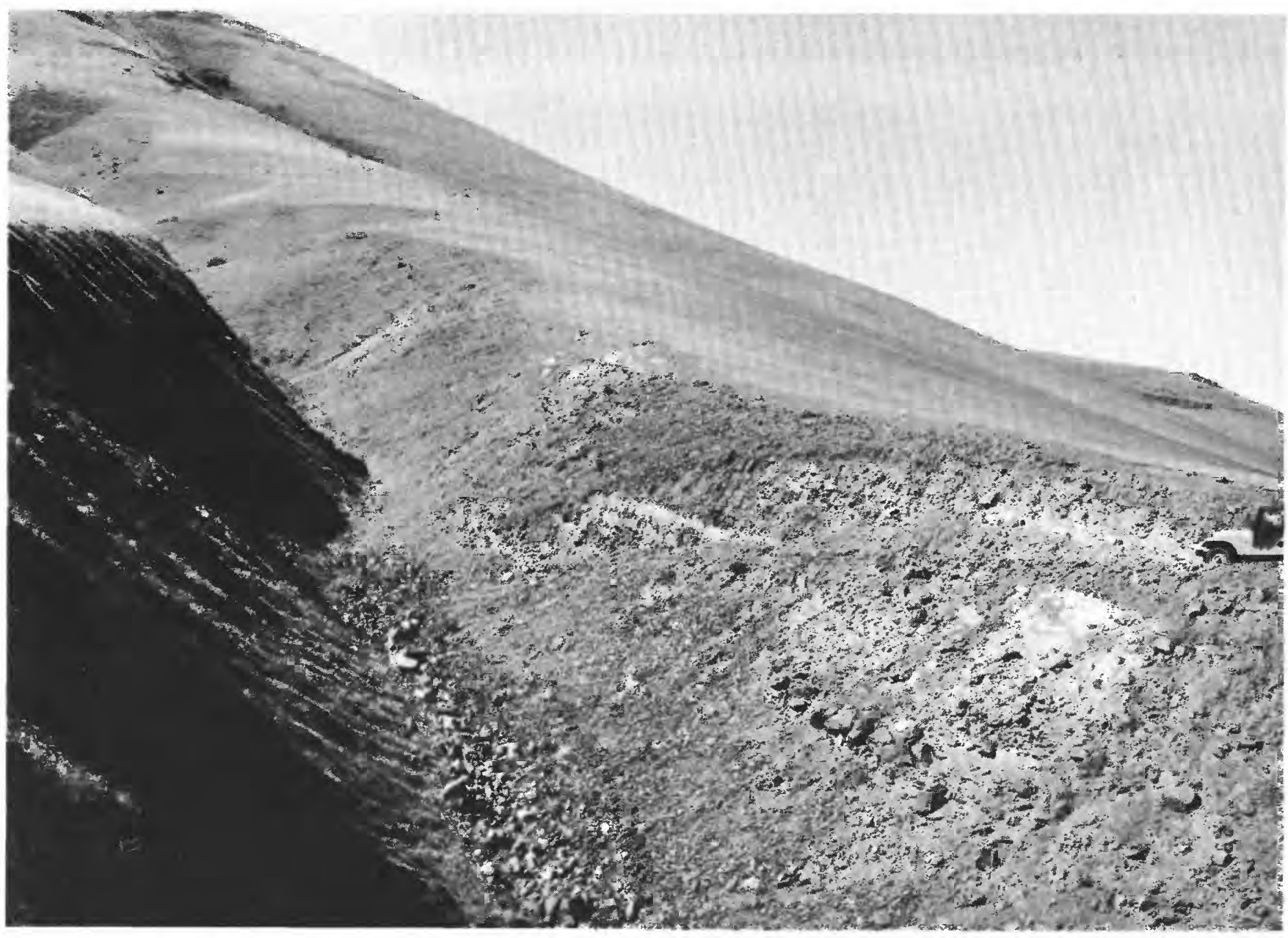

Figure 10.-Colluvium beneath mountain slope at southwest side of Haystack Butte. Deposit consists largely of rude bands of subangular basalt debris interbedded in thick zones of loessial silt containing scattered rock debris. Nearby, the colluvium is overlain by Pleistocene lava. The long colluvial slopes north of Maryhill Museum have been faceted by glaciofluvial waters to an altitude of more than a thousand feet. (See fig. 7.)

stratigraphic elements, generally separated from the flow above and below by a difference in jointing, texture, color, susceptibility to alteration, interbedded sedimentary materials, a common vesiculated top and a "flinty" basal section, or other horizontal characteristics that break the vertical continuity.

Regardless of its thickness at any one place, a lava flow may be the result of a single lava effluence or a laminated composite formed by several related, separately arriving effluences. Each part of the composite lava flow is defined as a flow unit. (The flow units in this area are much more extensive than the 300 -foot-wide and $1 / 2$-mile-long flow units which Nichols (1936) found common in lava in New Mexico and for which he derived this term.) A flow unit is a discrete part of a flow at a given place and was one single body of liquid lava that moved into the solidifying position. Flow units commonly have visible, but not always distinct, tops and bottoms; the contact zones between successive flow units show little or no oxidation, sediment, vesiculation, or evidence of stratigraphic interruption. The contacts between flow units in places are transgressed by jointing systems and in other ways were obliterated during the consolidation or late-liquid episodes of the adjacent lavas.

The distinctness of the top and bottom of some flow units differs from place to place; thus, a flow unit may in places be taken for a separate flow, yet be so indistinct as to go unrecognized nearby where petrologic or weathering conditions are different. In places, the lava of flow units mixed with the still-liquid parts of previous flow units or flows, an action which destroyed the con- 
tacts between them. Thus, the counting of flows and flow units and their thicknesses is partly arbitrary and has differed with the place, the time, and the observer.

Where the liquid lava flowed into water or over watercontaining materials, its globulation into pillows, pods, short lenses, and pipes is accompanied by a powdery or granular shatter product of partly hydrated and oxidized glass that may form an interpillow matrix of palagonite and tuff. This pillow lava is common in the top thousand feet of the basalt, and is especially prevalent in the top 500 feet east of Rowena. One pillow lava, about 100-150 feet below the top of the basalt, serves as a stratigraphic horizon marker from The Dalles eastward beyond the Deschutes River. Within that extent, the pillow-lava unit is exposed for several miles in the cuts of U.S. Highway 30 (old), near 200 feet altitude, eastward from the downtown part of The Dalles. Much of this extensive pillow layer (called the "highway pillow layer") has foreset bedding with $30^{\circ}$ dips to the south and west.

Lapilli and other granular basaltic ejecta, accompanied by yellowish sandy ash, occur as part of a thick flow, the third from the top, and underlies the surface (dip slope) east of Locke Lake, in sec. 35 , T. 3 N., R. $12 \mathrm{E}$. Such fragmental materials contribute porosity to small parts of the basalt and show that effusive "fountaining" accompanied the extrusion of some of the lava within this area.

For the most part, the basalt consists of successive flow layers so accordant that differences of $1^{\circ}-2^{\circ}$ in the general strike and dip are difficult to find. However, within the basalt, slight changes in dip are more common than is generally realized. Differences of $1^{\circ}-3^{\circ}$, due to local thickening or interflow subsidence, erosion, or other discordance-producing agencies, mark certain parts of the stratigraphic sections. These discordant parts are visible mainly where thick sections are exposed for great distances. One discordancy of about $3^{\circ}$ is present in the south wall of the Columbia Gorge just south of the town of Rowena. Others have been noted by previous workers elsewhere in the basalt region.

The stratigraphic top of the basalt lies on different laval flows in various parts of the area. Thus, the last of the basalt accumulation may be of slightly different age from place to place.

Some of the flows, especially those that are thick and resistant or petrologically distinctive, can be followed readily for many miles in canyon and mountainside outcrops, but even the very thick flows contain changes in petrologic details and in general appearance over distances of several tens of miles. Likewise, flows and flow units that are thin or discontinuous are interlayered throughout the vertical section of the basalt; thus, the flow arrangement in any one area is only partly related. to the arrangement in a neighboring area and largely or completely discontinuous with the flows occurring in some distant part of the basalt region. Among the distinctive parts of the basalt section in this area are: (1) the thick flow-breccia layer that occurs about 400 feet below the top of the basalt in the lower part of the Deschutes River canyon and in the Columbia Hills north of the Maryhill area, (2) the 150-foot-thick "wavy-column" flow that forms most of Miller Island and shows conspicuously in the gorge walls at the general altitude of 200-400 feet eastward from Celilo, (3) the top 500 feet eastward from Rowena Gap, a zone in which there are several widespread and many local pillow lavas, and (4) the massive 200-foot lava flow ("Mosier Palisades flow") which forms the top of the basalt westward from Rowena Gap (fig. 12).

The rubbly tops of some flows, the brecciated flows, and the highly jointed parts of some flows are the principal parts of the basalt that transmit water (Newcomb, 1959, p. 4-8).

The permeable parts of the laval layers occur irregularly, and individual aquifers may be either extensive or discontinuous. The percentage of the rock unit that is formed by the permeable strata at any one place can be expressed as an average which is derived from the number of aquifers and their thickness per given thickness of the basalt.

Observations and drilling data accumulated throughout the basalt region indicate that about three aquifers, 10 feet, 5 feet, and 1 foot thick, occur on the average in each 300 feet of the top 1,500 feet of saturated basalt. At an estimated effective porosity of 25 percent as an average for the aquifers, this thickness of aquifer would indicate that only about 1-2 percent of the volume of the whole rock mass contains sufficient drainable pore space to yield water to wells. Such statistical characteristics have been summarized as an average water yield to large-producing wells in the basalt. The average yield to 10- or 12-inch-diameter wells, percussion drilled to at least 300 feet below the water level and pumped at drawdowns of $50-100$ feet is $1 \mathrm{gpm}$ (gallon per minute) of water for each foot of well penetration below the regional water table (Newcomb, 1959, p. 14).

No single spring that yields more than $100 \mathrm{gpm}$ was observed flowing into the rivers from the main groundwater body, but there are many of small or moderate yield. The general smallness of the spring flows from the basalt, despite the potentially large capacities of some of the aquifers, clearly shows that spring discharge is limited principally by the amount of recharge 
to the ground-water body. The recharge limitation on the flow of springs is especially evident at the upland springs flowing from perched water.

Because a permeable zone is interrupted laterally in many places and eventually terminates, single aquifers generally are identifiable for only a few miles. The main aquifer exploited near The Dalles is known as "The Dalles Ground Water Reservoir" (Stanley, 1959) and has been identified over a more extensive area than most any other single water-bearing zone in the basalt region. This aquifer extends beyond the Dalles area for which it was named (fig. 16).

Inasmuch as the permeable interflow zones are known to terminate and to thin in places along the strike, it is to be expected also that some end downdip between impermeable layers. In such stratigraphic traps, ground water will remain perched or under artesian pressure, or both. At present, the location of such stratigraphic traps cannot be predicted, and their presence may be estimated best on a statistical basis.

The changes in thickness observed at the outcropping ends of aquifers indicate that the lateral percolation of water will be obstructed stratigraphically at some places, and that perched ground water must occur where an aquifer pinches out and the water cannot move downward through underlying rocks. Thus, in upland plateaus without structural reservoirs, perched water is stored mainly in aquifers of limited extent or low to moderate permeability.

The descriptions of the stratigraphic details of the basalt layers in this report are limited to those significant in the occurrence of ground water or necessary to the recognition of key points in the stratigraphic position of aquifers in the different parts of the area. Within the basalt the individual lava flows, or at least groups of lava flows, commonly are mapped in detail only in a relatively small area, such as one in which a major engineering feature is planned.

JOIN'S PRODUCED BY COOLING OF THE LAVA

Systematic cracks, or incipient partings, traverse the basalt. The main sets of cracks originated from the shrinkage of the solidified rock during its cooling. The most prominent joints are arranged in vertical columns which have a general hexagonal plan. Less conspicuous, but important, are systems of (1) flat, or sheeting, joints and (2) unsystematic miscellaneous partings that separate some parts of flows, especially basalt of a more glassy or flimly texture, into angular and irregular blocks of all sizes and shapes.

$323-7240-69-2$
In most flows, the sheeting joints are prominent in the top 5-10 feet and are numerous, but less conspicuous, in the bottom few feet. In the central parts of the flow they may be largely invisible or form only discontinuous partings that cut across the joint columns.

The columnar jointing systems are of several types; at least one type is present, in varying degrees of perfection, in almost every flow. The columns are generally perpendicular to the flow contacts and range from 6 inches to 6 feet in width. They commonly extend across a large part of a flow, upward from near the base to the rubbly top of the flow; they are more perfectly formed near the center of the flow or flow unit. Vertical systems of both wide columns and narrow columns transgress some flows, though one system is usually faint when both are present. At places within the top part of wide columns, narrow 3- and 4-inch-wide columns ("microcolumns") extend inward from the outer columnar surfaces, curve downward, and either become progressively less visible toward the massive center of each of the wide joint columns or become the top of a system of narrow vertical columns. The jointing system is generally uniform within a given flow, but great variations from this uniformity are present locally.

In accordance with the type and number of the joint patterns and the closeness of the spacing of the joints, the basalt may be broken into small blocks (like brickbats) or it may be separable into long blocks of wide columns. The joints generally are open for percolation of water near the surface, in the zone of weathering, or in deformed flows that have been stretched during tectonic movements; but in undeformed basalt flows the joints commonly are tightly closed at depth. Nevertheless, in some of the flows, even the tight joints afford an avenue for slow movement of fluids and gases, as can be seen in the deepest parts of tunnels, where some tight columnar joints permit water to move down as a slow transfer that feeds a drop-by-drop procession from protruding points. In flows lacking permeable shrinkage joints, the only fractures allowing water passage across the massive part of the basalt flow may be the regional joints, described next.

\section{REGIONAT JOINTS}

In addition to the common shrinkage joints, the basalt has major joints, some of which have been called regional joints (Trimble, 1950). These long straight sets of parallel vertical cracks trend in various patterns across most of the basalt. They belong to the type of rock rupture called extension fractures. They seem to 
be as prevalent in nearly horizonal as in tilted basalt, but they are more conspicuous and are best known in the areas where the basalt is near the horizonal.

Because they occur in many areas of underformed, or very slightly warped, basalt, they are believed to include some major cooling structures. However, some of the regional joints are parallel to some lines of tectonic deformation in the basalt. The displacement along the parallel tectonic deformations may be either a result or a cause of the regional joint fractures. Consequently, at this time, the regional joints might be considered a hybrid between nontectonic and tectonic structures.

On plateaus, regional joints parallel to, and near, escarpments form a plane of weakness from which the basalt may rotate toward the declivity. This movement is taking place along many escarpments like those on the old highway west of Mosier where, near the center of sec. 2, T. 2 N., R. 11 E., cracks as much as 1 foot wide have opened at the surface along the regional joints parallel to the nearby cliffs.

In places, the regional joints cut through several flows, and in other places they are restricted to one flow, below which they disappear in rubble zones at the top of the underlying flow. On the surface, the common regional joint extends straight across one flow for half a mile to 3 miles. It consists of (1) about a 10-foot-wide zone in which parallel vertical fractures, without displacement, are twice as closely spaced as are the vertical columnar jointing planes in the other parts of the flow, and (2) a central 1- to 2-foot-wide zone in which the same type of planoparallel fractures are still more closely spaced, separated by about one-sixth the distance across the nearby columns.

In general, the horizontal movement of ground water along the permeable zones seems to take place readily across the regional joints, probably because little or no movement has taken place along the joints, so the rubbly rock of the aquifers continues across them.

The regional joints may be conspicuously etched by stream erosion. Some of those that prominently cut the rock benches near Spearfish, northeast of The Dalles, and near Celilo are shown in part by the topographic contours on plate 1 . The more fractured rock associated with these joints has been selectively eroded in spectacular fashion by river currents. Part of this selective entrenchment is typical of the familiar "scabland-channel" type of erosion that characterizes the basalt in river channels of "The Dalles type" (Bretz, 1924).

\section{AUTOBRECCIATION}

Flow breccia, or autobrecciated lava, is produced where consolidated parts of a cooling lava have been moved by impulse of still-liquid lava beneath. Flow breccia is uncommon in the basalt, but the tops of some flows and the entire thickness of some thin flows consist of fragmental lava that may have been broken by lava flowage after some solidification had taken place. The extensive aquifer a hundred feet below sea level at The Dalles, previously identified as "The Dalles Ground Water Reservoir" (Stanley, 1959), is apparently this type of breccia (figs. 16 and 17). It is described further on page $\mathrm{C} 27$.

Aggregations of angular blocks of basalt 1-18 inches in diameter, arranged in apparent disorder, make up parts of some of the lava flows. In the canyon of the Deschutes River, the tributary Gordon Canyon, and the mountain slopes north of the Maryhill area, such a breccia, about a hundred feet thick, forms an inconspicuous but widespread layer whose outcrop is 400 feet below the top of the basalt. It appears to be autobrecciated basalt and should form an important aquifer in places where it could store water. At one place in Gordon Canyon (SE1/4 sec. 12, T. 1 N., R. 15 E.), the small summertime flow of Gordon Creek disappears into the top of this brecciated flow, and an equal quantity $(15-20 \mathrm{gpm})$ of water discharges from springs at the base of the brecciated flow a quarter of a mile farther down the canyon. The volcanic mechanisms that formed such rare flow breccias in these basalts created permeable zones of possibly great utility.

\section{INTERFLOW SEDIMENTS}

At irregular intervals, generally a few hundred feet apart stratigraphically, the contact zone between flows contains a sedimentary deposit. Observed in these interflows deposits were tuff, tuffaceous sand, silt, clay, diatomite, carbonized wood, coal, sandstone, conglomerate, and mixtures of these materials. The deposits are more numerous than commonly supposed, because they crop out only at the steepest places. Within this area, there are more of these interflow sedimentary deposits in the top thousand feet of the exposed basalt than in the lower thousand feet.

The interflow deposits range from 1 to 60 feet in thickness but generally are less than 10 feet. They taper to thin edges and become thicker and thinner irregularly along the strike. Some pinch out rapidly, whereas others, along a widespread stratigraphic horizon, consist of a great number of separate thin lenses that had accumulated in the sags of the rough top of the underlying lava flow.

The thickest such deposit observed is the 60 feet of tuff and sandy tuff that crops out below the uppermost 130 feet of basalt around Signal Hill, just east of The Dalles. This tuff underlies the extensive layer of pillow lava, called the "highway pillow lava," mentioned above. 
All the samples examined contained fragments of labradorite feldspar like that in the basalt; consequently, this tuff is considered a part of the basalt rather than an interfingering part of the Dalles Formation. This "Signal Hill tuff" interflow layer may continue north and occur sporadically in the Columbia Hills, where several landslides (pl. 1) of the basalt strata have occurred at unusually low angles of dip and a tuff was the incompetent layer in which the slide plane developed.

A 2- to 10-foot-thick silt zone containing wood and woody coal occurs intermittently along an interflow horizon about 250 feet below the top of the basalt between Mosier and The Dalles. A good exposure can be seen where woody coal is burning in the cut of the old highway around Crates Point at the north side of The Dalles Country Club (SW $1 / 4$ NE1/4 sec. 17, T. 2 N., R. $13 \mathrm{E}$.). A similar sedimentary deposit is exposed in the highway bank 5 miles to the northwest (NE1/4 NW1/4 sec. 4, T. 2 N., R. 12 E.), and one has been reported in several wells, particularly at a depth of 110-120 feet near Murdock, Wash., a mile east of the first exposure just described.

A possible stratigraphic equivalent of the above coalbearing silt bed is exposed 7 miles west-northwest of The Dalles Country Club-on the mountainside northeast of Bingan, in NE $1 / 4 \mathrm{NW}^{1} / 4$ sec. 20 , T. 3 N., R. $11 \mathrm{E}$. It consists of a bed of micaceous sand and white volcanic ash, which crops out about 300-400 feet below the top of the basalt. The width of the sandy soil underlying the mountain slopes at this place indicates that the bed must be several tens of feet thick in places, though only 7-8 feet of it could be observed in place along the banks of old logging roads. Under soil cover, it may continue southeast around the brow of the escarpment of the Columbia River Gorge, and may be the weak strata from which the top 400 feet of the basalt slid off the now-bare dipslope northwest of Locke Lake.

Most of the layers of pillow lava overlie a stratum of waterlaid sedimentary material, generally silty ash, diatomite, or sandy tuff. This sedimentary material extends up into some of the pillowed lavas as a result of either in situ interdeposition or physical intermixing caused by steam-accompanied injection of the sedimentary material into the stratum of lava.

\section{WEATHERING}

The basalt has a thin oxidation skin on most all joint surfaces and on all but newly broken faces. Artificial fractures have subconchoidal surfaces along relatively even planes that bound highly irregular shaped blocks. Within each flow, the basalt is largely fresh, undecomposed rock and lacks extensive secondary alteration of the minerals except in some places where weathering has penetrated differentially and in a fow zones where hydrothermal change has occurred. There is weak, spotty zeolitic filling of cavities and some reorganization of minerals in zones of fault brecciation.

Where the basalt has formed the land surface for a large part of its geologic history, it is decomposed to depths of as much as 50-60 feet and has been altered greatly by ovidation and selective leaching. Such deep weathering is present on Burdoin Mountain northeast of Bingen. Elsewhere, the basalt top is unweathered or only mildly weathered.

\section{FOIDS AND FAUITS}

MAJOR FOLDS

Two broad upwarps branch northeastward at the east side of the Cascade Range-the Bingen anticline and the complex structure, or anticlinorium, formed by the Mill Creek Ridge and Columbia Hills anticlines. To the southeast of these anticlines are respectively, the Mosier syncline and Dalles syncline. The average vertical displacement between these two main upwarps and their associated synclines, is nearly two thousand feet. The widths of the two main anticlines and two main synclines (from 4-8 miles) are generally similar except for the Dalles syncline, whose south flank is a regional dip slope many tens of miles long. Geologic sections across these major structural features are shown on plate 1 . The folds are symmetrical, in general, but contain some parts which are asymmetrical, dual, branching, faulted, or otherwise complex.

The Bingen anticline broadens north of the Columbia River, where its limbs become inconspicuous in the high plateaus north of Burdoin Mountain. It is almost terminated on the south by the east-west cross fault along Whiskey Creek. South of the fault which is followed by Whiskey Creek, the Bingen anticline is shorn of its west limb by the downdrop along the adjacent large northsouth fault.

The Columbia Hills anticline and its topographical equivalent, the Mill Creek Ridge anticline, are paralleled by the Dalles syncline on the south and by the Mosier syncline on the north. The compound uplift would be properly designated as an anticlinorium, but the shorter name Columbia Hills anticline, is used here to designate the compound uplift which extends from its southern end near Wasco Lookout (secs. 32 and 33, T. 2 N., R. 12 E.) northeastward and then eastward beyond this area. Its southern part, herein called the "Ortley segment," was named the Ortley anticline by Williams (1916, p. 122), who also named the Bingen anticline and the Mosier syncline. 


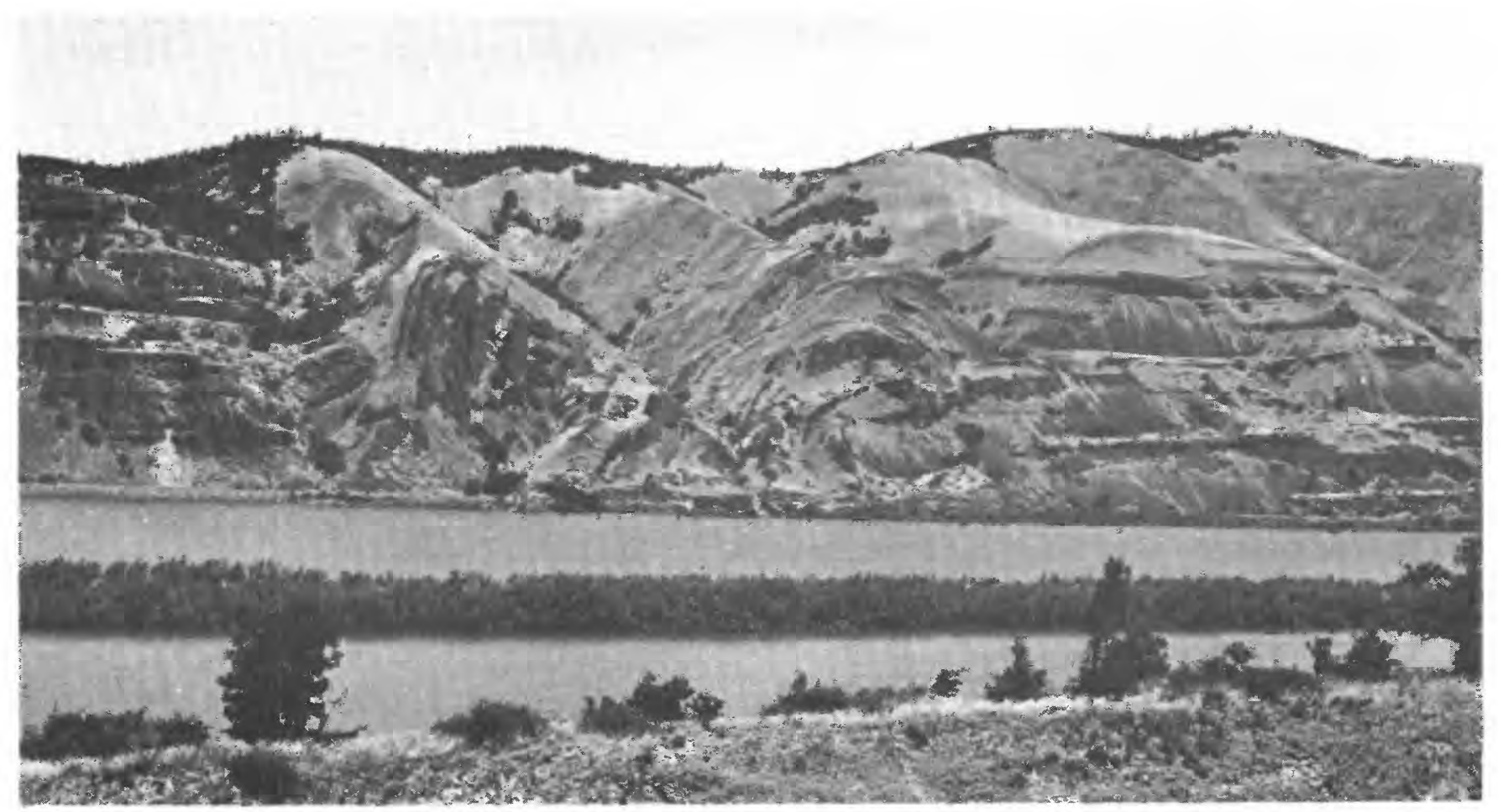

Figure 11.-View north across the Columbia River from Rowena. Part of the basalt in the asymmetrical fold of the Columbia Hills anticline reaches the vertical near river level. Flexural slippage is evident in the oversteepened limb.

To the northeast and east from Rowena Gap, the Columbia Hills anticline is divided into segments by sharp folds or faults which trend northwest obliquely across the main structure and continue to the northwest out of the area (pl. 1). Two of the segments have markedly asymmetrical cross sections. In the steeper sides of the asymmetrical sections of the anticlines and on the sharp turns, like that at Stacker Mountain (sec. 30 , T. 3 N., R. 14 E.), the basalt strata in places have been overturned, faulted, and thrust faulted. The mapping in greater detail of the structures at these places was precluded by the extensive brecciation, shear displacements, slump disturbances, and the colluvial cover, all of which are characteristic of these places of severe rock deformation.

In the south side of Rowena Gap, the two limbs of the Ortley segment of the Columbia Hills anticline are somewhat symmetrical. The northwest limb is much steeper in the first exposures north of the river. (See fig. 11.)

The western large downwarp, the Mosier syncline, begins as a gentle northward-plunging sag at the eastern side of Hood River Mountain. Six miles north of its beginning, its axial area forms the picturesque inwarddipping trough that is followed by the Columbia River south-southwest to Mosier (fig. 12). North of the Columbia River it becomes progressively broader and shallower, and is a barely distinguishable sag where it crosses High Prairie. It continues northeastward beyond the area, at least to where the basalt of the Columbia River Group is covered by young lavas near Goldendale, Wash., 9 miles northeast of the northeast corner of this area. Northeastward from near Stacker Mountain, another broad and relatively shallow syncline, the Swale Creek syncline, and a secondary anticline lie between the Mosier syncline and the Columbia Hills anticline. The Swale Creek syncline continues many miles eastward beyond this area (Newcomb, 1967, fig. 1).

South of the Columbia Hills anticline, the axial area of the broad Dalles syncline follows an almost imperceptible sag in the broad floor of a downwarped trough that extends northeast down Mill Creek from beyond this area. The syncline widens northeastward to where 


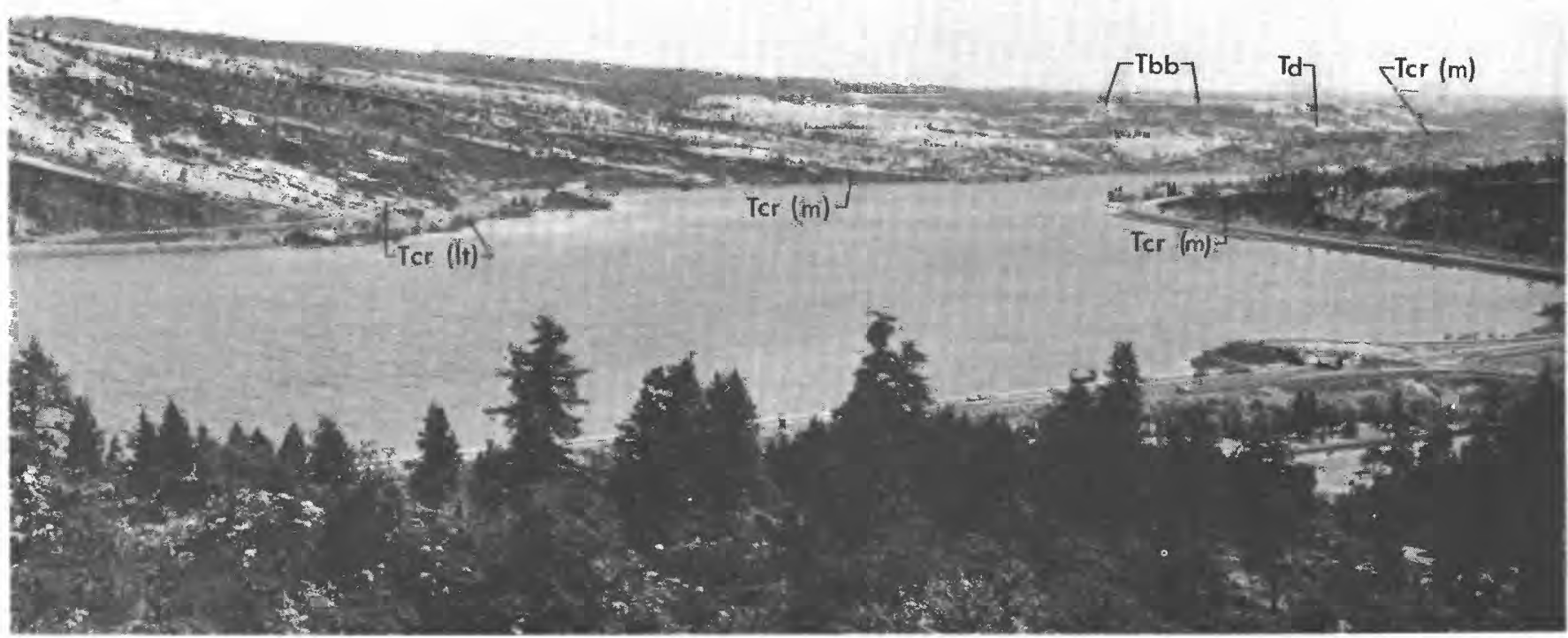

Figure 12.-View northeast along the trough of the Mosier syncline from an escarpment just west of Mosier. Highway exit to Mosier is in right foreground. Tcr $(\mathrm{m})$, the Mosier Palisades flow, the top flow of the basalt of the Columbia River Group in the Mosier area; Td, Dalles Formation. Tbb, basalt porphyry of the Balch Lake area; Tcr $(1 t)$, lapilli tuff, marks lava-fountain orifices in the basalt.

the flat-lying basalt is exposed at The Dalles and Dallesport. From this low struotural sag, the basin at The Dalles, the syncline curves to the east. For part of its length within this area, the nearly flat-lying basalt of the axial zone of this syncline is followed westward by lower Fifteenmile Creek and, farther east, by China Hollow Creek.

Far beyond this area, the Dalles syncline (Piper, 1932, p. 134) alines with the broad syncline of the Umatilla Valley (Hogenson, 1964, pl. 1) ; together they form the great structural downwarp which the Columbia River follows westward for 100 miles from Wallula Gap to Rowena Gap (Newcomb, 1967).

MINOR FOLDS

Several of the secondary folds or groups of folds shown on plate 1 are known to have some effect on the ground-water conditions and must be mentioned briefly here.

The most important of the subordinate features within the Mosier syncline are (1) the narrow anticline which underlies Rocky Prairie, and (2) the associated Orchard syncline. Flexural slip and flowage within the basalt layers that were bent in the narrow anticline have destroyed much of the permeability of the basalt near the axial plane of the anticline. The resulting impermeable breccia has caused the impoundment of ground water, as described in the section on "Local examples of structural control of ground water," page C23. (See figs. 2 and 15.) The flexural flowage (Donath and Parker, 1964), a type of brittle failure, is a common type of fault breakage widely distributed in the overstressed parts of the narrow and tight folds of the basalt.

Near the junction of Lugan and Government Flats, a shallow arch continues the narrow Mill Creek Ridge anticline through the uplands, where only the Dalles Formation is exposed. The anticline continues north of Chenoweth Creek as the small fold along the divide of Chenoweth and Badger Creeks and, with interruptions, has a continuation in the alined Wetle Butte anticline.

The Wetle Butte anticline forms the general ridge that divides the drainage of Badger and Chenoweth Creeks, crosses the lower part of Badger Creek, swings to the east across the scabland channel north of Foley Lakes (NE. cor. sec. 30, T. 2 N., R. 13 F.), traverses the sharp arch in Wetle Butte, and diminishes to nearly horizontal basalt at the east bank of the Columbia River. 
Possible structural equivalents of the Badger Creek syncline and other secondary structures south of the river occur northeast of the Columbia River as the set of short anticlines and synclines north of Smithville. Like the minor warpings just described in Chenoweth Creek valley, these folds seem to have resulted from shallow stress that was not relieved by, or was created by, the displacements of the major folds.

From Stacker Mountain eastward, the Columbia Hills anticline has many associated minor folds and faults. The folds that trend northwestward (in secs. 19 and 24, T. 3 N., Rs. 13 and 14 E.) from Stacker Mountain, the parallel smaller anticlines that lie to the south of the main axis, the prominent northwest-trending Warwick fault, the transverse Davies Pass syncline, and the northwest-trending fault crossing the Columbia River just below the railroad bridge at Celilo are some of the subordinate structural displacements important to the occurrence of ground water.

Several broad folds in the long, gentle south limb of the Dalles syncline bring the basalt near, or to, the surface. These folds and some associated, largely unknown, faults cause ground water to remain at comparatively high altitudes. One of these folds is an anticline which trends roughly parallel to the axis of the Dalles syncline and transverse to the regional dip of the basalt. The fold, herein called the Lash Ranch anticline, arcs across the valleys of Threemile, Fivemile, and Eightmile Creeks in the south part of T. 1 N., Rs. 13 and 14 E. It shows on the geologic map (pl. 1) largely as an "island" of basalt on Threemile Creek and a wider than elsewhere exposure of basalt on Fivemile Creek (Piper, 1932, pl. 11). Each of the creeks crosses this anticlinal axis and continues to the northeast after flowing eastward parallel to, or across, the syncline at the southern side of the anticline.

A sharp anticlinal bulge, which has a vertical displacement of about 200 feet, trends along the canyon slope south of Gordon Ridge, in the southeast part of the area. Just south of this Gordon Ridge anticline, an accompanying 100 -foot-deep structural sag forms the syncline followed westward by the creek in Harris Canyon to the Deschutes River (see fig. 13). East of Gordon Butte, both folds curve to the east-northeast. Beyond this area, the syncline forms the prominent sag followed eastward by Gordon Hollow and by springfed Grass Valley Creek, and the anticline forms a 100foot-high linear bulge that continues for many miles along the north of Grass Valley Creek.

\section{FAULTS}

Besides the minor faults and the dispersed faulting that is obscured in steeply folded parts of the basalt, there is major faulting within the Bingen anticline and there are two faults that have special significance to the tectonic and hydrologic situations.

The east-west fault along Whiskey Creek and the large north-south fault are parts of the strong deformation along the east side of the downdropped block which underlies the Hood River valley. Also, faults alined along the sides of the Columbia Gorge suggest that the river followed faults when cutting Bingen Gap across the Bingen anticline. A zone of fault-shattered basalt several tens of feet wide trends N. $40^{\circ} \mathrm{W}$, where it crosses the old Columbia River highway in the SW. cor. sec. 33 , T. 3 N., R. 11 E. North across the river, a nearly parallel band of fault breccia is exposed in the north-central part of Bingen along the lowest part of the basalt escarpment.

One of the faults of special tectonic and hydrologic significance is herein called the Chenoweth fault. It bounds the basalt along part of the southeast side of the Ortley segment of the Columbia Hills anticline (Piper, 1932, pl. 11 and p. 136) and continues westward to form the south limit of basalt exposed in the West Fork anticline. The fault was exposed by a test pit at the NE. cor. sec. 36, T. 2 N., R. 12 E., where a 1-foot-wide zone of clayey gouge separates the basalt hanging wall from the massive agglomerate of the Dalles Formation in the footwall and lies in a plane dipping $68^{\circ} \mathrm{N}$. At the divide between Mosier and Chenoweth Creek valleys, the alinement of the fault trace also indicates a reverse displacement, a dip north toward the upthrown side. West of the north-south offset, along a cross fault half a mile west of that divide, the main fault may be nearly vertical or may dip steeply southward, as it does in normal fashion along the north side of Kellar Creek canyon.

The Warwick fault, whose scarp forms the west face of the high ridge topped by Haystack Butte, trends northwestward along the sharp west faces of small domes alined across the Swale Creek valley. Beyond the area mapped, the trace of the Warwick fault follows a linear sag for 20 miles before it disappears under alluvium and young volcanic rocks in Camas Valley at a point only 15 miles southeast of the peak of Mount Adams. The fault was mapped by the writer a decade ago, and is shown on the geological map of Washington published in 1961. Where this fault crosses the Klickitat River 5 miles north of this area, it apparently forms a conduit along which carbon dioxide rises to the canyon floor. The gas is recovered commercially from springs and wells. The fault is one of several parallel strikeslip faults trending northwestward, about 3-8 miles apart, across the plateaus north of this three-quadrangle 
Gordon Butte

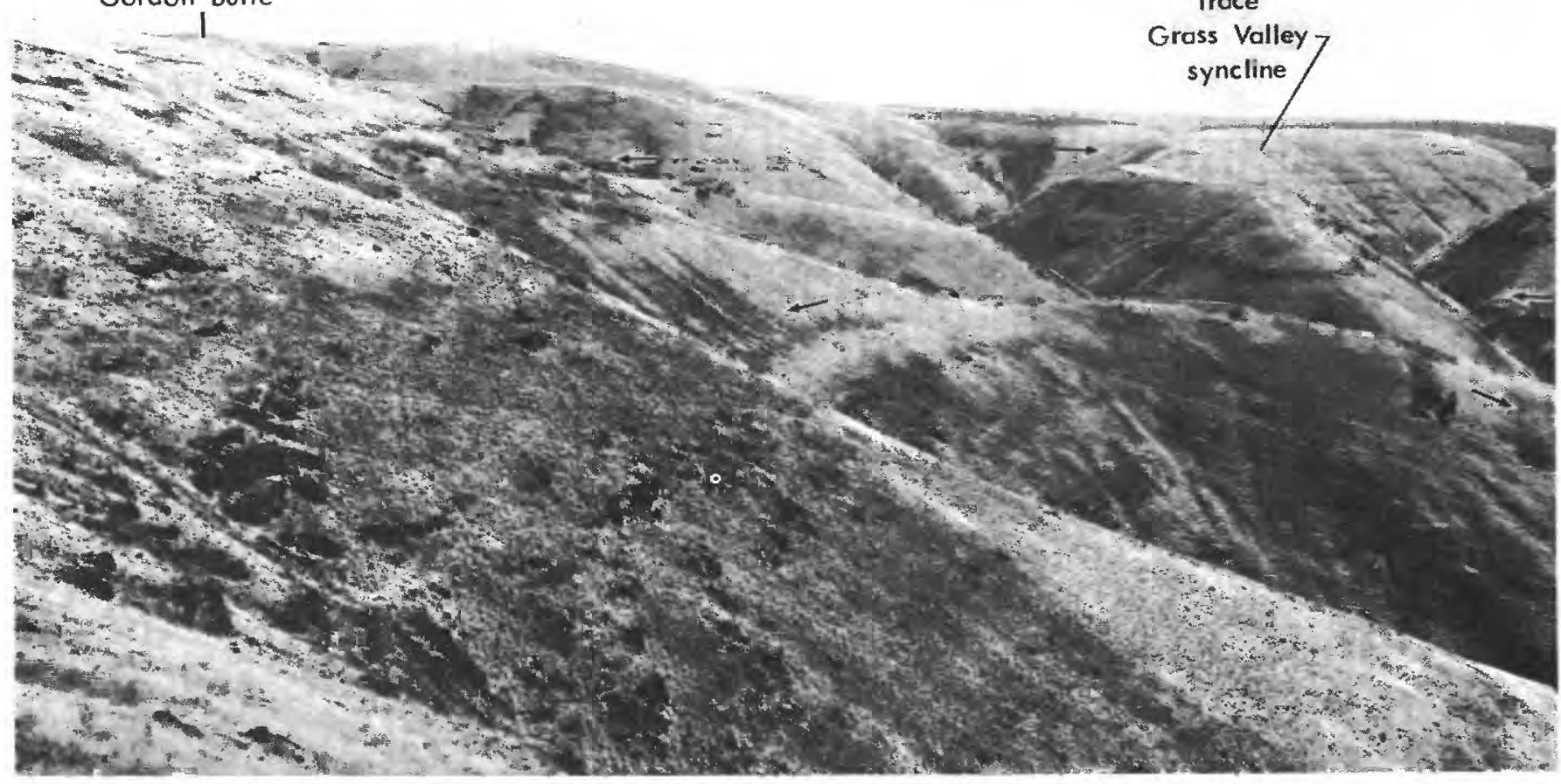

Figure 13.-View east along the upper part of the south slope of Gordon Ridge. The low anticlinal bulge transverse to the regional slope causes ground water to be impounded and to flow out along the Grass Valley syncline at the right. Arrows indicate dip of basalt flow away from the anticlinal crest and (at the right) into the adjacent syncline.

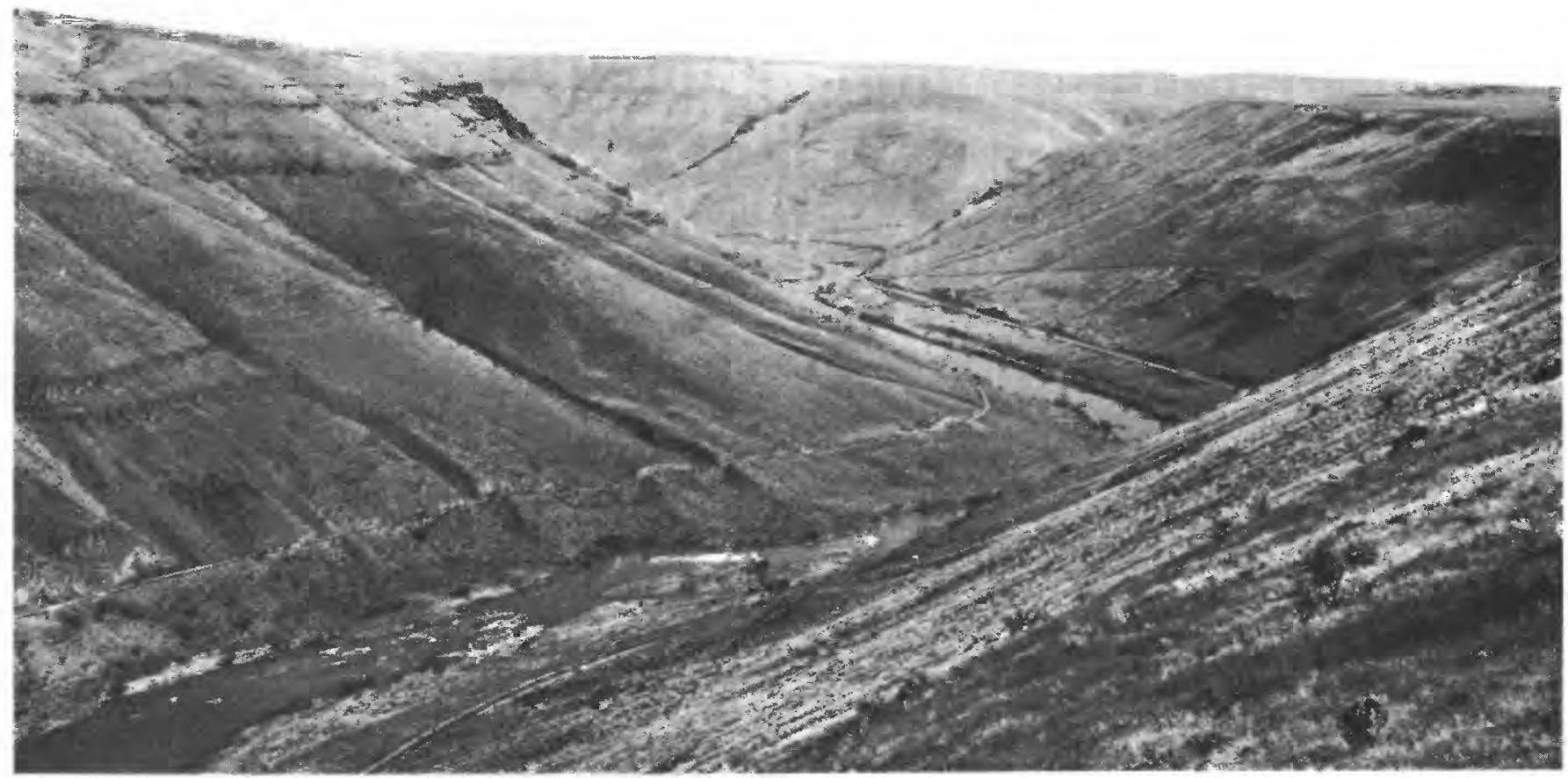

FIGURE 14.-View south from the west rim of the 1,000-foot V-shaped canyon of the Deschutes River. The unimproved grade of Free Bridge Road is evident along the west side in the right center ground. 
area. Much of their lateral slippage is taken up in the steeply folded parts of the Columbia Hills anticline. On the Warwick fault, strike-slip movement is southeast on the northeastern side. At its southeastern end, the fault curves toward an east-west alinement and divides into several slip planes whose displacements are absorbed in the steeply inclined basalt along the south limb of the Columbia Hills anticline.

Among many minor faults are some within the axial part of the Dalles syncline near the Dalles Dam, where a small fault (Piper, 1932, pl. 11) crosses the river just downstream from the Dalles Dam. The fault, called the Quarry fault in this report, is well exposed in a small quarry near the center NE $1 / 4$ sec. 1 , T. 1 N., R. $13 \mathrm{E}$. (pl. 1). Its eastern side is upthrown about 40 feet in the exposure at the south side of the former U.S. Highway 30. In the quarry, the fault is an irregular 18-inch-wide fracture and gouge zone, dipping $80^{\circ}$ to the northeast; on the eastern side of this fault, blocky basalt is raised opposite pillow lava on the western side. Some slippage seems to have occurred lengthwise, parallel to the strike of the fault. The pillow lava on the west side of the fault is the "highway pillow lava" exposed in the bank of the old highway westward to the downtown part of The Dalles.

\section{GROUND-WATER OCCURRENCES}

\section{TECTONIC CONTROLS ON THE GROUND WATER}

The tabular separation of aquifers within the general layered strata of the basalt, as described above, creates an arrangement by which folds and faults can exert a primary influence on the ground water. The effects of the deformation of the basalt on the ground water can be interpreted from some of the facts about water on the surface, from the water-bearing characteristics of the basalt, and from data on ground water. These structural effects on ground water in the basalt are largely (1) greater accessibility of the aquifers to recharge (water descending from the surface), (2) easier transfer of water downward and laterally along greater hydraulic gradients, and (3) larger and more numerous storage reservoirs of ground water behind structural barriers.

EASE OF WATER ENTRY INTO THE BASALT

Tectonic deformation, commonly followed by erosion, causes the basalt strata to be beveled by the land surface and makes the permeable zones accessible to infiltration. This ease of entry for water is especially evident in anticlinal mountains, which receive some of the greatest amounts of precipitation. Also, it is evident in ravines and stream valleys that cross tilted basalt.
Examples of the influence of structure on the infiltration and discharge of ground water occur (1) on the crest of the Columbia Hills anticline north of The Dalles, where rainfall and melting snow infiltrate into erosion-bared permeable strata, (2) at springs in the ravines farther south, where those permeable strata are again exposed, (3) in Gordon Creek where the summertime flow of the creek disappears into an exposed flow breccia, and (4) in the aquifers of the Orchard syncline, which are filled to the altitude at which they crop out in Mosier Creek farther south, as explained on page C23.

A summary of the examples seen would class the beveled aquifers crossed by gravel-bedded streams as the greatest potential sites for ground-water recharging, and the horizontal basalt flows of great plateau extent as the least likely sites for recharge. Intermediate between these extremes is the tilted basalt cut by canyons - a condition common in this area.

\section{DOWNDIP, A PREFERENTIAL DIRECTION OF GROUND-WATER MOVEMENT}

After it infiltrates the basalt, water moves downward along interblock spaces, joints, and other fractures until it reaches the base of a zone of permeable rock. In most of the basalt, this base of a permeable zone lies along an irregular stratigraphic horizon in the top part of the dense center of a lava flow. In horizontal basalt, the hydraulic gradient away from the point of infiltration is small because the amount of vertical head, which at the maximum could be no greater than the thickness of saturated rock, must furnish the drive to distant outlets of the aquifer. By contrast, it is apparent that a dip of the basalt as low as $3^{\circ}$ would provide a drop of 277 feet per mile in the aquifers, and the potential hydraulic gradient due to the tilt would greatly exceeed the gradient due to saturated thickness of any horizonal aquifer.

The rapid drainage away from points where water infiltrates into the upper end of dipping aquifers is illustrated by the waterless condition of level areas on anticlinal crests where permeable basalt is beveled and also by the loss of water from creeks where they flow onto aquifers inclined toward distant outlets. The location of springs predominantly on the updip side of stream courses which trend transversely to the inclination of basalt (p1. 1) illustrates the preference of the ground water for downdip movement. (Note the springs in China Hollow and Fifteenmile Creek valleys and in Rock Creek valley southwest of Mosier, pl. 1.)

OBSTRUCTION OF PERCOLATION IN AQUIFERS

The downdip movement of water is interrupted, in places, by tectonic structures. A synclinal sag or fault, 
transverse to the downdip direction of ground-water movement, causes underground accumulation of water.

The commonest type of obstruction to ground water in tilted basalt results from a rise of the relatively impermeable base of an aquifer. Where it occurs in a long dip slope, such an obstruction starts at the edge of the transverse anticline that creates the synclinal sag in which ground water accumulates. Commonly, ground-water impoundment by such a structure - an anticlinal barrier-occurs both in perched ground water and in ground water below the main water table. The storage of water in such obstructed parts of the aquifers will increase to the level where spillage over the barrier, to land surface, or to other aquifers, or the leakage to underlying rock, equals the inflow from updip. Springs discharging to streams that trend transverse to the regional dip commonly occur at these synclinal sites; several examples are evident on the map (pl. 1) and are described beyond.

From these observations of the common impoundment of ground water in layered basalt upgradient from an anticline, a spill of ground water would be expected to occur where the base of each equifer crosses the axial plane of a mildly warped anticlinal barrier (figs. 17 and 18). This spill at the anticlinal axis within each separate aquifer would result in a vertical drop of the water table at the axial plane. It also would cause the successively deeper aquifers within the synclinal reservoir to have successively lower water levels (fig. 18). Such a postulated change in ground-water levels at the crest of an impounding anticline could not be evaluated fully in this area. Indication that this kind of a multiple-level spillway occurs at the axis of the mildly warped Lash Ranch anticline could be interpreted from the different water levels in the Martin (32G1), the Stark (28R1), the Elton (22R1), and the Renken (22B2) wells on Threemile Creek. The altitudes of water levels in these wells are, respectively, 1,340, 880, 180, and 90 feet. Several other wells have water levels that may be explained by similar geologic conditions. Full field demonstration of such successively lower levels of ground water, because of successively lower stratigraphic spillways in aquifers crossing the crest of a nonfaulted anticline, awaits more data, but the existence of the phenomenon is suggested by observations here.

Besides the upturn of the aquifers in anticlines, the most common obstruction to lateral percolation is the crushed rock, or the offset, along a fault plane. The faults in this area are the sites of rock movements that ranged from minor displacements along breaks associated with folded structures to great shear displace- ments along major fractures of the earth's crust. Most known faults in this area are near vertical.

Fault zones block the percolation of ground water by destruction and offset of the permeable zones of the basalt. The amount of movement necessary to create such a barrier varies with different aquifer thicknesses and ground-water pressure. Along normal faults, barriers result from movement of only a few tens of feet. One fault, along which the walls are displaced about 4 feet (see fig. 6), is not a significant barrier to the ground water, whereas another the "Quarry fault", with 40 feet of displacement, occurs between wells having water levels differing by 100 feet in altitude and seems to cut off the aquifer laterally. The completeness of the water shutoff differs at each barrier and along any one fault, where stoppage may be complete or partial at different places and in different aquifers.

Fault breccia and gouge are much less permeable in a horizontal direction than were the permeable parts of the unbroken lava flows. Water may seep slowly across some of these breccias and cause some leakage from fault-barrier reservoirs, but the fact that water is not transmited readily is demonstrated by the great difference in water levels on opposite sides of fault barriers (fig. 16). Water does seep at a slow pace vertically along some planes in the fault-zone breccias, where no vertical movement of water would occur if the rock mass consisted solely of well-layered, near-horizontal basalt.

MAJOR OCCURRENCE, BENEATH THE MAIN WATER TABLE

The graded rivers maintain a sloping base level to which ground water drains. This drainage level is near the top of the continuous zone of saturation in the earth's crust, which is known as the water table. To distinguish it from the numerous local perched water tables in this report, the water table is designated "the main water table." In most places, the main water table has adjusted upward to the new river levels maintained artifically in recent years.

In wells that tap aquifers at a level lower than a nearby river, the static water level generally is near the level of the river. Wells at Bingen, Lyle, Mosier, Rowena, The Dalles, Moody Station (26P1), Wishram (17L1), Biggs, Maryhill, and other places tap ground water standing near river level. The yield of wells tapping ground water below the main water table depends largely on the thickness of basalt and, hence, the number of aquifers drilled below the water table (Newcomb, 1959, p. 10).

Because the layers of the top 2,000 feet of the basalt are exposed to the rivers that bevel the two main anti- 
clines, a good opportunity exists for interflow between the ground water and the river. The ground-water levels in wells tapping highly permeable aquifers near the rivers show evidence of this intermovement of surface and ground water except in a few places, such as "The Dalles Ground Water Reservoir," a notable exception described on page C27.

Locally, the main water table is slightly higher or lower than the river nearby owing to some confinement of, or to some artificial draft upon, the ground water. The water percolates toward the rivers, and its height above the river-level control at any place is theoretically related directly to the amount of water available for transmission and to the resistance the rocks give to percolation toward the discharge points.

In roughly comparable areas, natural gradients of the main water table have been observed as low as about 6 feet per mile near Lind, Wash. (Walters and Grolier $1960, \mathrm{pl} .2)$, and as high as about 30 feet per mile in the Walla Walla River valley below College Place (Newcomb, 1965, pl. 1, table 1).

At some distance from the rivers, the nearly horizontal main water table may lie at great depth below the land surface. As the land surface ascends to the plateaus or up the steep ungraded valleys of the tributary creeks south of the Columbia River, it rises many hundreds of feet above the position of the main water table. Normally, the main water table would be a little above the 72-foot altitude at which the river, westward from The Dalles, is usually held by Bonneville Dam. On the plateaus, deep wells to tap ground water below the main water table have been drilled only south of The Dalles. The water levels in the Renken well (22B2) and the Blaser well (13N1) stand at an altitude of about 90 feet. Both wells are 3 miles from the Columbia River and have water levels comparable to that in "The Dalles Ground Water Reservoir" prior to the 50-foot decline of the water level due to pumping from that aquifer during the period 1955-65.

\section{MINOR OCCURRENCES}

Besides the principal body of ground water beneath the main water table, ground water occurs in distinct bodies perched in the basalt underlying the plateaus. The perched ground water may be loosely designated by the relative height of its position: (1) high perched and (2) intermediate perched. Locally, either or both of these may discharge to streams flowing in valleys at local base levels high above the main water table. However, another distinction between the two subdivisions is that the intermediate-perched water generally is accompanied by permanent streams, such as Fifteen- mile Creek, whereas the high-perched water may discharge to intermittent streams or evaporation areas. Ground water impounded as a result of structural or stratigraphic conditions occurs in these perched positions as well as beneath the main water table. Most of the ground water (at any level it may be stored in tilted basalt) is confined under pressure; consequently, at any of the three positions (main water table, intermediate perched, and high perched), ground water may have a high pressure level in relation to the land surface, and even may flow from wells.

\section{HIGH-PERCHED GROUND WATER}

Where the basalt is at, or close to, the land surface, the uplands are moderately well supplied with ground water for grazing and farmstead purposes. This supply of water comes mainly from small springs flowing form the top 200-300 feet of the basalt or from wells tapping water in those strata. Of the precipitation which falls on the plateau tops, only a small percentage gains entry to the basalt-probably less than 10 percent. The infiltration varies from place to place and apparently increases directly with the total precipitation, the granularity of a thin soil cover, the accessibility of aquifers, and other factors, such as the prevalence of snowdrifts. As described above, a gentle dip of the basalt favors the beveling of the flows and facilities this infiltration.

In places, massive parts of the basalt layers perch the water and lead it back to the surface in prominent horizons, where the springs commonly occur on the updip side of transverse declivities. Most of the upland springs are small (less than $10 \mathrm{gpm}$ ), and the outflow evaporates, again infiltrates, or in a few places heads a permanent creek that reaches the main stream. These spring branches flow generally above the level of lower ground-water bodies; hence, their courses are marked by water disappearances. Thus, in the dip-slope plateaus, basalt layers upon which water is perched function somewhat like the shingles of a roof in that they return to the surface much of the small part of the infiltration that escapes past the soil zone and allow only a still smaller part to pass to the deeper aquifers

\section{INTERMEDIATE-PERCHED GROUND WATER}

Beneath some plateaus, the vertical distance between the high-perched ground water and the main water table is as great as 500 feet or more. Between the two, perched ground water occurs in some basalt layers. This ground water of intermediate level generally is irregular in extent and may occupy any zone between the water that is high perched and the main water table. It 
may stand at about the level of a stream, such as Fifteenmile Creek, and many saturate several basalt flows besides the one on which the stream flows. In a highplateau, semiarid environment, where about the only recharge is by water leaking down from above, these intermediate perched zones generally lack even moderate amounts of recharge and support only weak springs of the stock-water and domestic-supply type, but they can have considerable water in storage. Locally, where it originally contributed water to a baseleveled stream, a thick saturated zone provides moderately large yields to wells; some of these aquifers yield as much as a few hundred gallons per minute to a well. Such an aquifer (possibly the stratigraphic equivalent of the "highway pillow lava" at The Dallas), about 60 feet below the top of the basalt, annually afforded the Cherry Hill (23D1), Jack Martin (14M1), Wagonblast (14L1), and a few other wells in Threemile Creek valley with several hundred acre-feet of irrigation water for about 15 years before its storage became so depleted that other water sources had to be obtained (Piper, 1932, p. 155: Stanley, 1959).

\section{LOCAL EXAMPLES OF STRUCTURAL CONTROL OF GROUND WATER \\ MOSIER CREEK BASIN}

Two wells (1M1 and 2J1, pl. 1) 800 feet south of the riverbank at Mosier penetrate the basalt to about a hundred feet below river level. The water they obtain is harder (172 and 209 parts per million) than is usual $(50-150 \mathrm{ppm})$ for water in the basalt. This more mineralized water may rise from deep in the open-stretched joints along the axis of the Mosier syncline; it occurs with a water level equivalent to the main water table, slightly above river level. About 2 miles southeast of the Mosier wells, four irrigation wells (7E1, B2. H1, and Q1) in the basalt have water levels at altitudes near 490 feet, a little more than 400 feet higher than the water of the aforementioned wells at Mosier. Intervening between the two groups of wells is the tightly folded Rocky Prairie anticline, an uplift of about 300 feet, with a width of only a thousand feet (Newcomb, 1963). The basalt exposed in the water gap, which Mosier Creek has notched into the anticlinal ridge, includes some breccia that was formed by a grinding flexural flowage of the basalt near the axial plane (fig. 15).

The slippage of basalt strata over each other in folds has been progressively more disruptive where the radii of curvature became smaller. In tightly folded basalt, the individual joint blocks within flexed layers have been rotated with a resulting brecciation of that elongated section of the rock. This type of mechanical ac- commodation of rock to the stress was an integral part of some of the folding. It has been called flexural flowage (Donath and Parker, 1964, p. 49).

The basalt aquifers, which provide the high-standing water to these wells, should crop out in the stream canyons to the south. By stratigraphic projection (fig. 15), the points of overflow of the aquifer can be expected to occur in Mosier Creek above the forks in sec. 19 , where the altitude is about 500 feet.

In addition to the above description of the ground water in the Orchard syncline, a basinwide appraisal of ground water inflow to streams in the Mosier Creek valley was made from measurements taken at intervals along the creek in late summer.

A gaging of Mosier Creek when it consisted only of water effluent from the ground is given below, with the measured discharge listed in order ascending upstream. Numerous small springs flowing from the basalt near creek level could be observed at the time of gaging, but no large springs were seen. No spring discharge was evident from the Dalles Formation. The part of the flow provided by upland springs is from perched water in the Cascade lavas.

These measurements indicate a steady downstream gain in creek flow amounting to about $0.20 \mathrm{cfs}$ (cubic feet per second) for each mile of flow over the basalt

Flow in Mosier Creek and tributaries September 12, 1962

[Measurements by William A. Hart, U.S. Geological Survey]

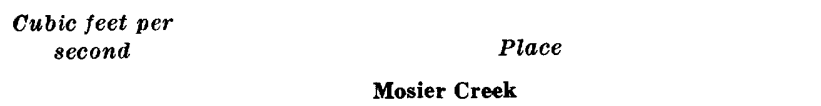

3.24 $2.84 \ldots 0 \mathrm{ft}$ below bridge, $300 \mathrm{ft}$ below forks, in NW $1 / 4$ NW $1 / 4$ sec. 19 , T. 2 N., R. 12 E.

$2.40 \ldots \ldots$ In northern part of $\mathrm{SE}^{1 / 4} \mathrm{NE} 1 / 4$ sec. $1, \mathrm{~T} .1 \mathrm{~N} ., \mathrm{R}$. 11 E., 0.4 mile above mouth of Honeysuckle Oreek.

.90_-_._._. Just above mouth of McVey Spring Creek, in SW $1 / 4$ sec. 14 , T. 1 N., R. 11 E.

.55 23, T. 1 N., R. 11 E.

${ }^{1} .05$

\section{Tributaries}

10.05

1.35_._._._- Unnamed branch, enters $1 / 2$ mile below Ketchum Ranch Fork. ${ }^{2}$

.66

19._... Indian Creek near mouth. ${ }^{2}$

32 spring flow from basalt).

\footnotetext{
1 Estimated.

2 Water flows from Cascade lavas.

3 Weir.
} 


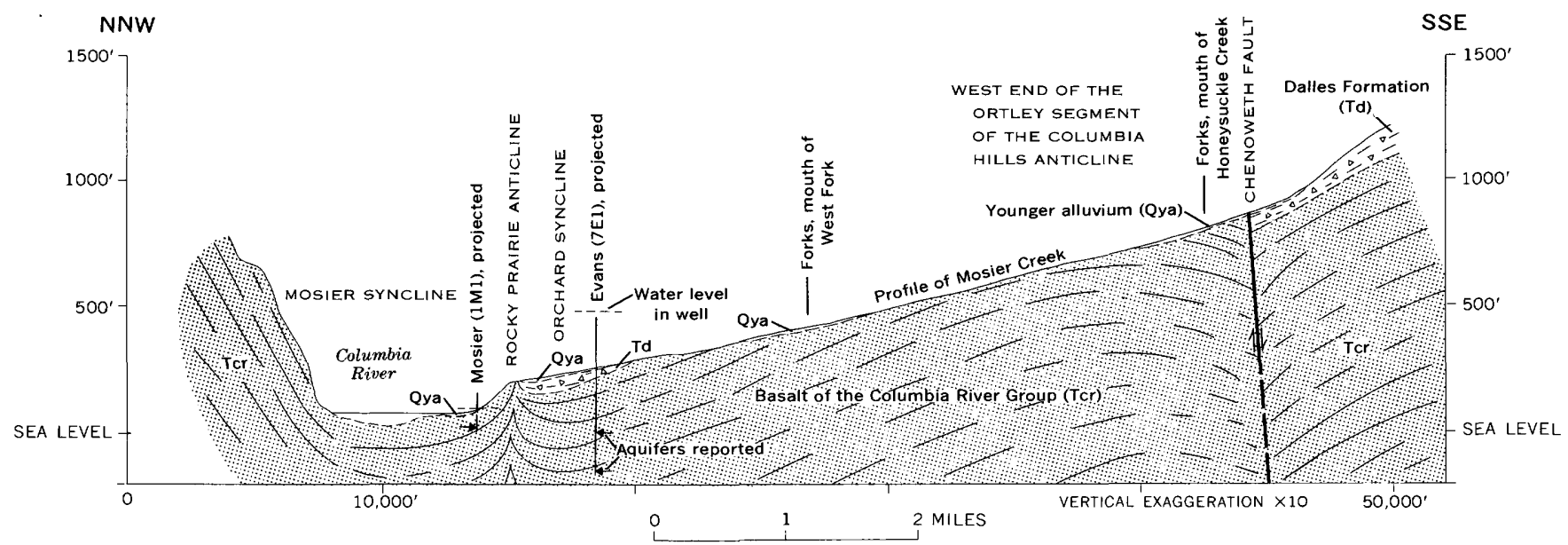

Figure 15. - Section along Mosier Creek. (A partly idealized profile of the creek with most items projected at right angles onto a line drawn between the $\mathrm{S}^{1 / 4}$ cors. of sec. 26 , T. 3 N., R. 11 E., and sec. 7, T. 1 N., R. 12 E.)

and could be interpreted as showing a gain per mile of $0.4 \mathrm{cfs}$ over the Dalles Formation, plus a total inflow of 1.35 cfs issuing from ground water perched in the Cascade lavas. However, of the $1 \mathrm{cfs}$ of water not known to flow directly from the basalt or the volcanic rocks of High Cascades, the largest part ( $0.84 \mathrm{cfs})$ enters the first 2 miles upstream from the south edge of the basalt and may come to the creek in the first half a mile above the mapped edge of the basalt. The south edge of the basalt, as mapped on plate 1 , lies along the Chenoweth fault. Barriers in the basalt along that fault could block the northward percolation and cause the ground water to rise to the level of Mosier Creek. Just upstream from the Chenoweth fault, the basalt occurs at shallow depth beneath a cover of the Dalles Formation and bouldery alluvium. It may be assumed from the geologic relations that the ground water rises from the basalt and emerges unseen through the course alluvial debris of the creek valley. If this assumption is correct, about 53 percent of the 3.24-cfs flow was emerging from ground water in the basalt.

The indicated 3.24-cfs base flow, if prevalent as the ground-water discharge to Mosier Creek throughout the year, would indicate a natural discharge of ground water equal to about 1 inch of water per year over the 50-square-mile drainage basin of Mosier Creek. However, if we assume that the Dalles Formation allows virtually no water to pass through it to reach the ground water, 53 percent of the ground-water outflow comes from about 8 square miles of basalt and 47 percent comes from about 12 square miles of Cascade lava. These yields would be equivalent to 2.92 inches of precipitation over the area of exposed basalt and 1.68 inches over the Cascade lava area. The 2.92-inch yield for the basalt of this more humid western part is much greater than the estimated amount of recharge received by the basalt of the plateau terrain in the less humid eastern part of the area, described on page C30.

The West Fork of Mosier Creek is nourished by meager spring flow largely from perched ground water. Late in summer, the start of the creek is a small spring flowing from ground water perched in the Cascade lavas. From the edge of these lavas, the creek consists of a flow of about $0.033 \mathrm{cfs}(15 \mathrm{gpm})$ northward to the basalt. In its 2-mile course across the basalt, the creek receives the flow of numerous small springs and increases to about $0.25 \mathrm{cfs}(110 \mathrm{gpm})$, at which rate the flow continues in the succeeding 2 miles across rocks of the Dalles Formation. In the last half mile across the basalt and alluvium, the creek is near the main water table and again gains water; it empties 0.35 to $0.45 \mathrm{cfs}$ into the main stem. The $0.22 \mathrm{cfs}$ contributed to this stream by the perched ground water from beneath a thousand acres of basalt terrain would indicate an annual yield equivalent to 1.6 inches of water per year. This area of basalt thus yields perched ground water to the stream at a unit-area rate of 55 percent of the average rate of 2.92 inches derived just above for the discharge, mostly from the main ground water, of the basaltic part of the whole Mosier Creek basin.

The springs that flow from the basalt and reach the West Fork of Mosier Creek occur at intervals along the lowest part of the valley slopes at 2,200-1,400 feet altitude. This spring discharge is from perched ground water and is returned to the surface by peculiarities of permeability along the aquifers. In contrast to the perched water flowing to the West Fork, the principal discharges from the basalt to the main stem of Mosier Creek are believed to come from ground water below the main water table. The contributions from below the 
main water table are believed to result from ground water having been impounded behind the Rocky Prairie anticline and the Chenoweth fault.

CHENOWETH CREEK BASIN

The southeast side of the Ortley segment of the Columbia Hills anticline is drained by Chenoweth Creek. Its main tributary, Brown Creek, integrates runoff from what was formerly a large segment of the Mount Hood Flat erosion surface, now partly preserved in Government and Lugan Flats.

The upland surfaces bevel at low angles the bedding planes of the tuff and tuffaceous agglomerate of the Dalles Formation. The thickly layered strata exhibit a rather phenomenal capacity to exclude water and to hold it in the thin soil zone. This surficial perching of water on the Dalles Formation has been exploited by the construction of many shallow ponds for livestock water. The basins are scraped 3-6 feet deep in upland sags and drainageways. Most ponds have water a foot or so deep throughout the summer because of the seepage that percolates laterally out of the basal part of the thin granular soil on top of the hard, massive, and durable tuff agglomerate. Several dry excavations, such as one in the SW. Cor. NW1/4 SW1/4 sec. 2, T. 1 N., R. 11 E., slow that similar ponds constructed where the basalt underlies the upland surface will not store water because of the greater permeability of the weather-loosened basalt.

There are many small seeps and springs flowing from the fractured basalt and the landslid basalt along the upper part of Chenoweth Creek, but they are insufficient for a permanent creek flow. Brown Creek receives small seepages from the Quaternary lakebeds and from slidedisturbed material, but it has no through flow during the driest months of the year.

About a dozen wells are used for irrigation of the valley plains and benchlands along Chenoweth Creek between the mouths of Brown Creek and Badger Creek. The altitude of Chenoweth Creek drops from 440 to 160 feet in this 2-mile segment, and the level of the ground water descends about on the same grade, from 450 feet at the mouth of Brown Creek to 250 feet at the northernmost well half a mile south of the mouth of Badger Creek.

The drillers' records show that these wells tap water in what has been considered to be coarse-grained and permeable materials of the Dalles Formation. The wells range in depth from 130 to 450 feet and in yield from 50 to $500 \mathrm{gpm}$; they make possible the only large water withdrawal reported to be from the Dalles Formation.
One well (30N1) was reportedly drilled 3 feet into basalt (389-392 ft), at which time the water level rose from an altitude of 210 feet to 270 feet. The data on all these wells fail to demonstrate whether they draw water from the Dalles Formation or from the underlying basalt. The basalt crops out about 800 feet to the west of well $30 \mathrm{~N} 1$ and may occur at shallow depth beneath some of these wells. If such large amounts of water were derived primarily from the Dalles Formation, these yields would be exceptional. The permeability in the Dalles Formation is known to be low in nearby wells. The lack of permeability is indicated also by the reports that the 605-foot Walters well (30B1) obtained no water in the Dalles Formation and had to be drilled about 200 feet into basalt to obtain water. The basalt of that well yields water abundantly, but the water level stands at an altitude of only about 50-60 feet.

A part of the Chenoweth Creek basin warranting special mention is Badger Creek, which drains a synclinal subbasin along the southeast flank of the Ortley segment of the Columbia Hills anticline. The southern part of the synclinal trough is titled northeast so that it plunges to a low point near the south line of sec. 24 . The water-yielding capacity of the basalt is not adequately tested by the present domestic wells, but those wells do show that the static levels of the ground water in the basalt are near land surface in the low part of the syncline and farther below the surface in wells outside the axial area of the syncline.

\section{MILL CREEK VALLEY}

Drilling and pumping records reveal that the Mill Creek basin includes a variety of ground-water occurrences in the basalt.

Mill Creek proper and the North Fork of Mill Creek flow from the more humid environment southwest of this area. The flow of Mill Creek is independent of any discharge directly from the basalt, except for the small amount that enters the North Fork within the Mill Creek Ridge anticline.

The North Fork enters the area with an average base flow in late summer estimated at about $0.15 \mathrm{cfs}$, and receives additional water from small springs flowing from the basalt and from the alluvial or landslide materials. Its base flow in late summer increases downstream until its rate is about $0.5 \mathrm{cfs}$ where the canyon starts across the beveled edges of the basalt strata in the Mill Creek Ridge anticline near the center of sec. 25, T. 1 N., R. 11 E. In this part of the canyon, the flow increases until it is about $1 \mathrm{cfs}$ where the creek leaves the basalt at the north line of sec. 31. From there downstream, 


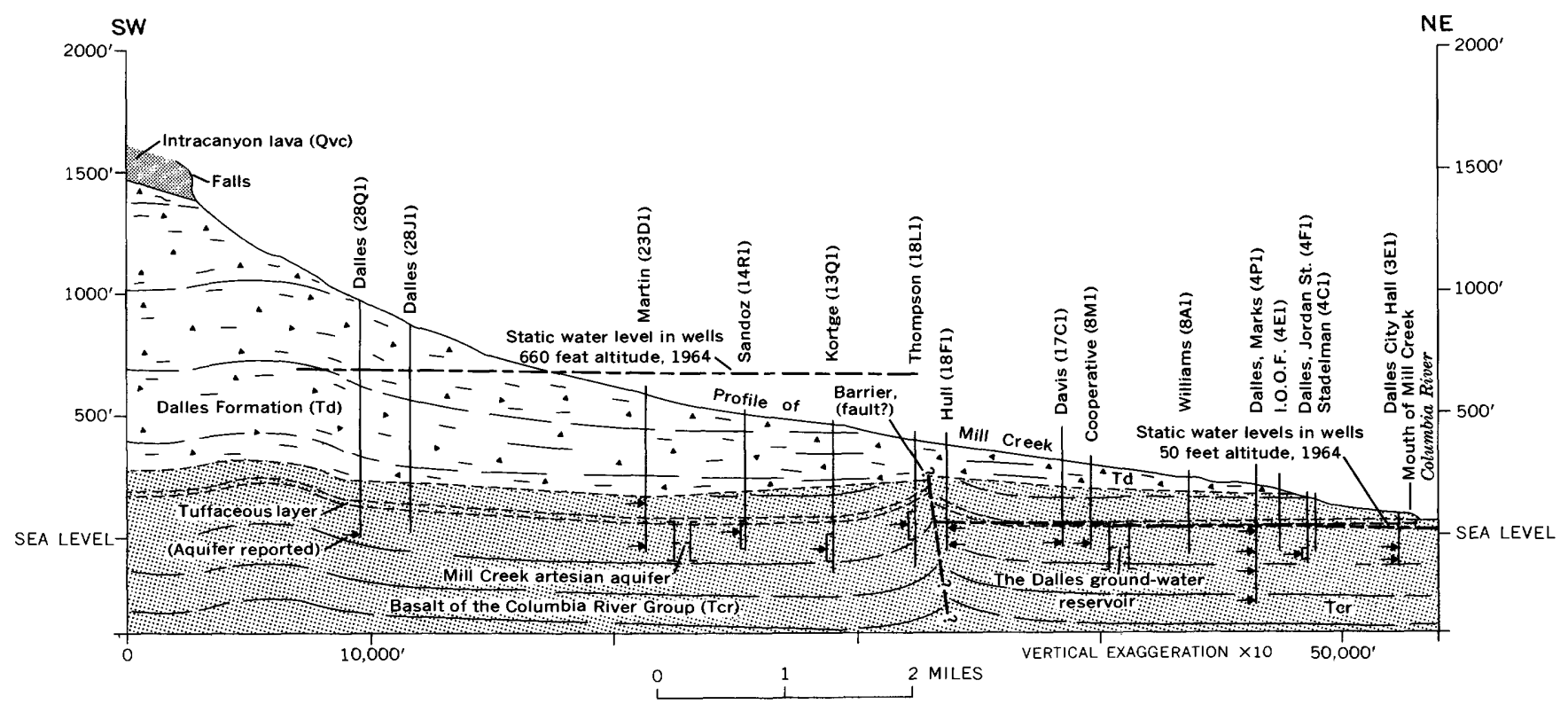

Figure 16.-Section along Mill Creek. (Profile of the creek; well information and geologic data projected at right angles to the section which trends through the Dalles City well 1N/12-28Q1 and through the mouth of the creek.)

full irrigation use and reuse is made of the creek flow. Its natural low flow remains near 1 cfs downstream to its confluence with the main creek in sec. 22 .

The flow of Mill Creek is gaged in the $\mathrm{SE} 1 / 4$ sec. 28, about halfway between Wicks Reservoir and the south line of sec. 28. The natural flow in late summer is only about $1.5 \mathrm{cfs}$; it is augmented by diversion of about 4 cfs from outside the basin. Downstream from Wicks Reservoir, the creek flow is altered by the diversions to the public-supply system of The Dalles, irrigation diversions and returns, spring-water inflow, leaks from the city lines, and occasional additions of water from deep wells.

As shown by the cross section (fig. 16), the highpressure artesian ground water, tapped by wells in the commonly called "Mill Creek artesian aquifer," extends south up Mill Creek valley from a barrier in sec. 18, T. 1 N., R. 13 E. at least as far as the highest well yet drilled, the city well (28Q1) above Wicks Reservoir. The five wells tapping this artesian water beneath Mill Creek valley withdrew an estimated 5,000 acre-feet of water during the period 1958-1964. The water level in the Sandoz well (14R1), a suitable index for the aquifer, declined from 188 to 172 feet above the surface during the 7 years 1957-63 (Jack E. Sceva, assistant State engineer, oral commun., 1963). The temperature of the water is $82^{\circ} \mathrm{F}$, which is $10^{\circ}$ warmer than the water in "The Dalles Ground Water Reservoir."
The completeness of the barrier at the downvalley end of this artesian zone is remarkable. As shown in figure 16 , the difference in water level across this barrier (between the Hull well, 18F1, and the Thompson well, $18 \mathrm{~L} 1$ ) was originally about 600 feet. This great difference in water level occurs even though the drillers' records, the stratigraphic knowledge, and the well information (fig. 16) do not indicate great displacement, but do show a flexure of the basalt extending toward this structural barrier. The rock structure which causes this barrier has no surface expression recognized as such at this time; it has not been determined whether this fault displacement took place before or after the deposition of the overlying Dalles Formation. The possibility that it is a post-Dalles Formation fault, whose displacement is obscured in the massive agglomerate of the Dalles Formation, is not entirely excluded by the evidence at hand.

In an attempt to locate and delineate this barrier, five traverses of the ground were made in February 1966 by a commercial firm using a portable proton-type magnetometer with a reading sensitivity of 10 gammas. Three traverses northeast-southwest along the valley floor parallel to a line between the Thompson well (18L1) and the Hull well (18F1) showed a negative anomaly of 100-200 gammas occurring in a band 50-75 feet wide trending $\mathrm{N} .17^{\circ} \mathrm{W}$. through a point 100 feet west of the northwest corner of Donation Land Claim 44. A parallel traverse on the bluff along the southeast 
side of the valley obtained an anomaly of 250 gammas over a band 125 feet wide along the same trend. Either the fifth traverse, along the valley slope on the northwest side, failed to record an anomaly along this band, or the presence of the anomaly was masked by much larger negative changes produced by an orchard irrigation pipeline. Three of the magnetometer traverses also showed a positive anomaly of 100-300 gammas about 125 feet southwest of, and parallel to, the negative anomaly. The plotted lines of the magnetic reading along the five magnetic traverses are generally similar. The trend of the negative anomaly apparently represents the trace of a fault in the basalt as detected through the overlying 140 feet of Dalles Formation. The band of the negative anomaly is shown as a dashed fault on plate 1. This band alines with ravines so as to suggest a band of greater erosion in the Dalles Formation, but excavations along this trace would be necessary to identify faulting, if present in the Dalles Formation.

\section{"THE DALLES GROUND WATER RESERVOIR"}

Beneath an area of about 30 square miles centered on The Dalles, the main producing wells tap water confined in a widespread stratum of rubbly basalt breccia at about 100 feet below sea level. This highly productive aquifer was formerly called "The Dalles aquifer" or "The Dalles pool." It extends beneath the Dallesport bench on the north side of the Columbia River and the lowland northwest of The Dalles as far as Wetle Butte. It also extends east as far as the Quarry fault near the Dalles Dam, and south for about 3 miles from The Dalles. The water level in this aquifer originally stood about 77 feet above sea level, which was about 20 feet above the natural average level of the river at the port of The Dalles (Piper 1932). Subsequently (1938), the normal river-pool level at The Dalles was raised to an altitude of 72 feet by Bonneville Dam, and, in 1957, the river above the Dalles Dam was raised to 160 feet. However, the water level in this aquifer did not rise in accommodation to either change in river level. The level of the ground water has been pumped down to an altitude of about 23 feet (1964) and is declining about 5 feet per year. (See fig. 16.) In 1958, this aquifer was officially named "The Dalles Ground Water Reservoir" in a declaration of a "critical ground-water area" by the State engineer of Oregon (Stanley, 1959). Close observation of water levels and studies of artificial recharge were begun by Dalles City in cooperation with the Oregon State Engineer and the U.S. Geological Survey (Foxworthy and Bryant, 1967).
As shown in the cross section (fig. 16), the artificially depressed level of the water in "The Dalles Ground Water Reservoir" extends up. Mill Creek valley to a point between the Hull well (18F1) and the Thompson well (18L1). South of the Hull well (18F1), a fault, as described previously, impounds ground water under flowing artesian pressure. On the two sides of this structural barrier in sec. 18, there is now a difference of about 650 feet between the level of the ground water in the same water-bearing stratum.

Elsewhere, the boundaries of the area beneath which the water level is declining rapidly in "The Dalles Ground Water Reservoir" are partly known from wells. On the south, the Renken well (22B2) on Threemile Creek taps this aquifer and has water levels comparable to those of "The Dalles Ground Water Reservoir," as does the Blaser well (13N1). The Elton well (22R1), on the north limb of the Lash Ranch anticline, apparently taps ground water that has an intermediate level. When the Elton well was first drilled, an aquifer having perched water with a static level of 160 feet below the surface was developed; however, the well was later deepened to obtain greater yield and entered a more permeable layer at 719 feet. Because this deeper aquifer had water at a lower pressure level, the upper water flowed downward. The level of the composite ground waters is 600 feet below the surface, at an altitude of about 200 feet. Thus, the present information indicates that the distinctive water level of "The Dalles Ground Water Reservoir" extends south to a transition zone near the axial plane of the Lash Ranch anticline. South of this anticline, the ground water stands at higher levels, as described below.

On the east, the boundary of the "Dalles Ground Water Reservoir" seems to follow the Quarry fault, which crosses the river just below the Dalles Dam. The well (1F1) of the Threemile Irrigation Cooperative taps water in this part of the aquifer, but the motel well (1A1) and two wells (36F1 and L1) at the Dalles Dam tap water under different hydraulic conditions, mostly with water levels that conform to river levels (Jack E. Sceva, assistant state engineer, oral commun., $1965)$.

The northern limit of "The Dalles Ground Water Reservoir" seems to be the tightly folded Wetle Butte anticline. The Fred Wetle irrigation well (29G2) just south of Wetle Butte taps ground water of the "Reservoir," but the water level in the Marsh well (20H1) just north of the butte originally stood at the level of the Columbia River. The northern boundary of the "Reservoir" east of the Columbia River is poorly known, but it may continue eastward from Wetle Butte, along 
a tectonic structure, across the Dallesport bench. The Tidyman well (27B1), in which the original altitude of the water was reported to be 185 feet, is north of the boundary, but well 34L1, and other wells at the airport, tap aquifers with water levels comparable to those in the "Reservoir" (fig. 17). The boundary may continue from Wetle Butte along one of the east-west faults as far as the northern continuation of the Quarry fault, as shown provisionally on plate 1 and figure 17.

There is a perplexing question as to why the ground water in the aquifer segment known as "The Dalles Ground Water Reservoir" lacks hydraulic connection with the Columbia River. The aquifer occurs along the river no lower than a hundred feet below sea level. The river has plucked (Bretz, 1924) the basalt along joints and faults to form deep trenches that extend more than a hundred feet below sea level ${ }^{1}$ in many places downstream from the Quarry fault. Thus, the present geologic information indicates that there should be hydraulic connection, but the records of water levels in the wells show that connection is lacking between the river and the ground water in this segment of the basalt aquifer. The isolation of this ground water is an important phenomenon on which data collection and study need to be continued.

Though the hydraulic isolation of "The Dalles Ground Water Reservoir" seems to restrict its recharge to the water that leaks from the higher ground water of the surrounding basalt, the aquifer constitutes a conduit-reservoir that is extensive and lies beneath an area where cheap sources of water are desired. It needs only a better recharge system. From the 30 -square-mile extent and from the apparent thickness of at least 25 feet of rubbly basalt having at least 20 percent effective porosity, the "Reservoir" is estimated to have a total capacity of about 100,000 acre-feet of water, only a small part of which has been withdrawn. Large quantities of good-quality surface water are easily at hand for artificially recharging this natural water-storage and waterdistribution facility.

THE UPLANDS WEST OF THE CANYON OF THE DESCHUTES RIVER

South of The Dalles, the Lash Ranch anticline curves across the regional northward dip of the basalt. The anticline creates an important synclinal sag on its south side. This syncline trends in a broad curve from southwest to southeast through the valleys of Threemile, Fivemile, and Eightmile Creeks. At low altitudes in this syncline, the ground water of the basalt rises in wells to about valley-plain altitudes. The ground water of

1 U.S. Army Corps of Engineers, Portland District, 1956, unpublished maps of soundings taken at and near the site for the Dalles Dam. the highest principal basalt aquifer stands near the surface at an altitude of 960 feet in the Dick Brothers well (36K1) in Jap Hollow (see fig. 17), at 680 and 980 feet respectively in the Oades well $(25 \mathrm{~N} 1)$ and the Wright well (34L1) on Fivemile Creek, and at 830 feet in the Stark well $(28 \mathrm{~N} 1)$ on Threemile Creek.

In five of the six flowing artesian wells in upper Threemile Creek valley, the water levels are much higher than they could be because of the barrier effects of the Lash Ranch anticline alone. Even if a complete hydraulic barrier existed along the anticlinal axis north of the Lash (32H1), Martin (32G1 and G2), Skirving (32E1), and Sanders (33M1) wells, the water would move laterally away from the area of these high pressure levels, above 1,300 feet altitude, if it were free to do so. Unless lateral barriers are present also, the high-level water would move toward Fivemile Creek 4 miles to the east, where the level of the ground water is 300 feet lower, or toward the Mill Creek artesian aquifer to the northwest, where the level is 600 feet lower. At present, the nature, position, and extent of the lateral barriers that confine the high-level artesian water of Upper Threemile Creek valley are only partly known. Records of future drilling, close geologic study, and geophysical tools may help to determine the boundaries of these important bodies of high-level ground water.

Ground water occurs in the basalt beneath the upland valleys west of the Deschutes River at three general levels: the high-perched ground water, intermediateperched ground water, and main water table.

Small springs issue at many places from the uppermost layers of the basalt. This effluence of high-perched water forms the common domestic and stock supplies of the uplands. In Standard Hollow, Douglas Hollow, and Stecker Canyon and on the top benches along the $\mathrm{Co}$ lumbia River, the discharge from the stronger springs results in late-summer creek flows as great as $50 \mathrm{gpm}$, most of which infiltrates or evaporates before reaching the perennial streams. Over much of the plateaus south and east of The Dalles, the top layer of the basalt is a pillow lava, which seems to accept infiltration readily and to allow ground-water movement downdip. Many of the domestic supplies are from wells or springs tappings this high-perched water. The wells are drilled through the Dalles Formation and obtain water in the first hundred feet or so of the basalt. The springs flow from the top of the basalt which is hidden in many places by slump from the overlying Dalles Formation.

The intermediate-perched water stands near the levels of the upland creeks and locally saturates layers about midway between the top of the basalt and the main 


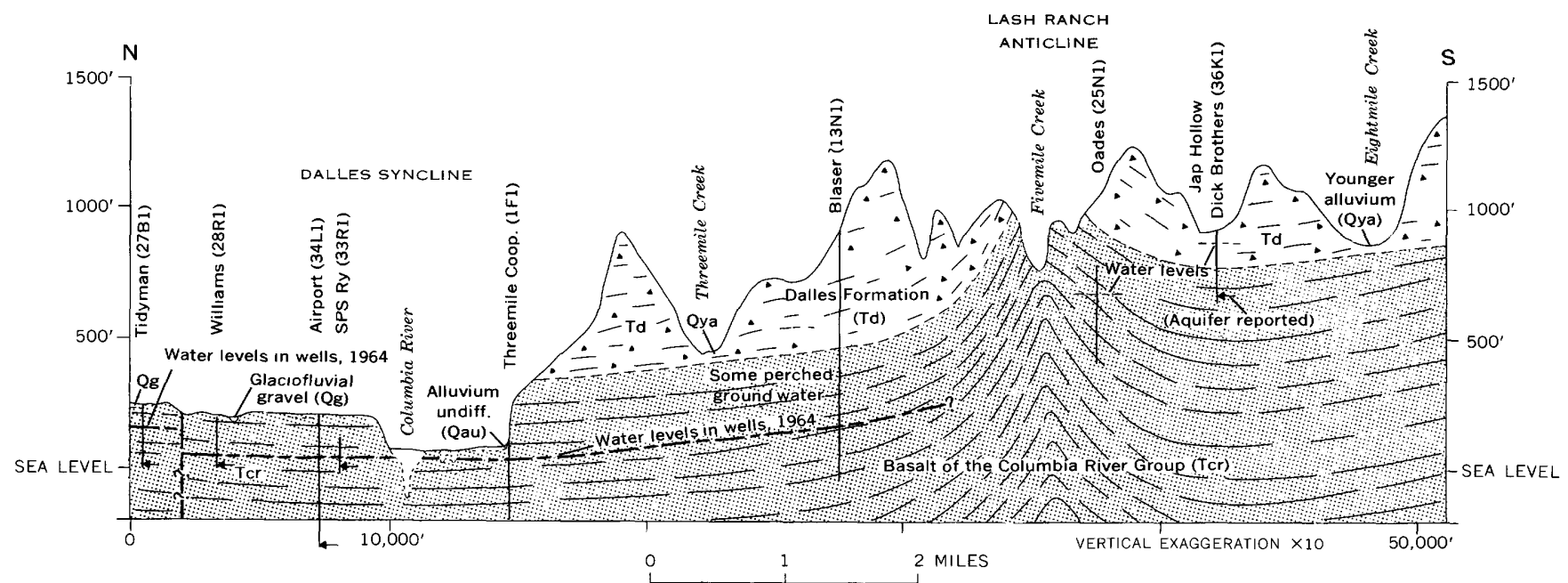

Figure 17.- Section north-south through The Dalles. (Hydrologic data projected to a geologic section along a line from the Tidyman well, near the N. $1 / 4$ cor. sec. 27, T. 2 N., R. 13 E., through the Dick Brothers well in Jap Hollow.)

water table. In the valley plains of the uplands, many of the domestic wells have been drilled 50-100 feet below the level of the creek and have obtained adequate water from the basalt. Most of the wells tapping zones of intermediate-perched water are pumped at rates of only a few tens of gallons per minute; the largest use of the water is for irrigation of lawns and gardens. The general similarity of the altitude of the ground water and the creeks, as well as the persistent flow of small springs to the creeks, indicates that there is some interplay of the water in the creeks and this intermediateperched ground water. During the late summer, these creeks receive almost no runoff from the surface and only small amounts from the high-perched water; yet, despite much diversion for irrigation, water flows at intervals in Threemile, Fivemile, and Eightmile Creeks below an altitude of 400 feet, and below 600 feet in Fifteenmile Creek. Within the central or axial area of the Dalles syncline, Fifteenmile Creek has had an average natural flow of about 1 cfs during August and September of recent years, despite considerable evaporation and withdrawals for irrigation.

The thicknesses of the stratigraphic zones saturated by this intermediate-perched water are only partly known. In certain places, several aquifers may be present, and the lowest ones may lie near the level of the main water table. One of the deepest wells drawing water from one of these zones is the 300 -foot Petroff domestic well $(2 \mathrm{~N} / 14-32 \mathrm{H} 1)$, which has a static water level 10 feet below the surface, about equal to the level of Fifteenmile Creek nearby.

Much of the perched water trickles from outlets on hillsides and canyon walls, but that developed by wells in some of the creek valleys has levels similar to the levels of the streams. The geologic mapping shows that the streams flow across gently inclined layers of the basalt in such a way that good interchange of surface water and intermediate-perched ground water could occur locally.

Outside the area underlain by "The Dalles Ground Water Reservoir" in this plateau segment, the water below the main water table has not been tapped extensively by wells. The main water table, or its equivalent piezometric surface, occurs generally at Columbia River level in wells beneath the uplands south and southeast of The Dalles, as described on page C28. In the future, the deep ground water beneath the main water table may become important to lands in these creek valleys of intermediate altitude, such as lower Fifteenmile Creek.

\section{PLATEAU GAST OF THE DESCHUTES RIVER}

The ground-water conditions north of Gordon Ridge are much like those of the equivalent plateaus west of the canyon of the Deschutes River. The physiography of the two plateau segments also is similar, except that the larger creeks east of the Deschutes River have steeper gradients along more direct routes to the Columbia River and drain less dissected upland valleys. Beyond the first mile or so away from the river, the creek valleys are cut no more than 200-300 feet below the plateau surfaces.

The high-perched ground water occurs in a manner similar to that described for the plateaus west of the Deschutes River and the Columbia Hills uplands. However, the outflow of water here is mostly from one zone- 
commonly about 200 feet below the top of the basaltor, in places, from an aquifer of secondary importance at the top of the basalt. Springs yielding $10-50 \mathrm{gpm}$ from this main stratum of perched ground water emerge from the southern, the updip, side of Harris Canyon. The northward flow of this perched ground water is abundantly evident in Grass Valley Creek east of this area. Ground water flows from this same zone, where it crops out in the creek valleys $2-10$ miles north of Gordon Ridge. In the canyons of the northward-draining streams, the springs occur at intervals downslope from where the entrenchment first reaches the depth of the perched ground water about along the north line of T. $1 \mathrm{~N}$. The consistent stratigraphic control of the outflow from this high-perched ground water is especially striking where the water emerges near the axis of the Dalles syncline in Spanish Hollow Canyon 2 miles south of Biggs Junction (pl. 1). Fulton Canyon, followed by the east (main) branch of Fulton Creek, is floored with sufficient alluvium that the spring flows, upstream from sec. 19, enter the stream channel inconspicuously. The spring flows entering Fulton Canyon Creek in its course north from sec. 33, T. 2 N., R. 6 E. constitute its latesummer flow of about $0.5 \mathrm{cfs}$. The west branch of Fulton Creek also receives numerous spring flows, totaling about $0.25 \mathrm{cfs}$, downstream from the uppermost spring near the high way curve in the NE. cor. sec. 31.

The late-summer inflow of all perched ground water is estimated at about $1 \mathrm{cfs}$ each to Fulton and Spanish Hollow Creeks. The only ground-water withdrawals of more than domestic- or stock-water supplies obtain enough perched water for irrigation of a few tens of acres of pasture. They are from a shallow well dug in a spring area in NE1/4 SE $1 / 4$ sec. 33 , T. 2 N., R. 16 E., and a 200-foot drilled well in the east-central part of sec. 16, T. 1 N., R. 16 E.

Erosion along the Grass Valley syncline in Harris Canyon has brought out perched ground water and caused the creek to entrench tranverse to the regional slope. The syncline here is only the small western end of the long transverse syncline followed eastward by Grass Valley Creek.

The main water table lies deep below this plateau east of the Deschutes River. As nearly as can be inferred from only a few wells along the rivers outside the plateau itself, the main water table beneath this plateau is near the level of the river.

\section{LOCALITIES NORTH OF THE COLUMBIA RIVER}

The deeply canyoned lowest part of the Klickitat River (fig. 4), the nearby rock benches along the Columbia Gorge (fig. 12), and some tributary canyons lie within the Mosier synchine. Only small amounts of perched ground water flow out into these canyons, and well-defined aquifers containing high-perched and intermediate-perched water seem to be lacking. Structural control of the ground water is displayed only by the downdip movement of water to small springs, but the topography shows that the inclination of the basalt also helped to determine the locations and shapes of the stream valleys.

Several 200- and 300-foot-deep wells at Lyle (3G1) obtain industrial and public supplies from the basalt below the main water table.

One general example of the effect of tectonic structure on the chemical quality of the ground water was evident in this part of the area. The unusual occurrence of very hard water in the Mosier wells (172 and $209 \mathrm{ppm}$, hardness as $\mathrm{CaCO}_{3}$ ) contrasts with the $50-150 \mathrm{ppm}$ commonly occurring in water from wells in the basalt and shows that the basalt in some parts of the Mosier syncline may contain ground water that is slightly more mineralized than elsewhere. Apparently this harder water rises from greater than usual depths by way of fissures caused by cracking along the axis of the syncline.

High Prairie has only meager domestic and stock supplies available from small springs that flow at, or near, the top of the basalt at the heads of canyons in this locality of flat-lying basalt. These small springs seem to be nourished by the infiltrated melt water of snowdrifts. Only a few scattered small springs drain from the 800-foot-thick section of basalt exposed in the sides of Swale Creek canyon, and this part of the creek is dry during most of the summer and fall.

The anticlinal structure of the Columbia Hills directs ground water, as well as surface water, north and south from its axial crest. Northeast from Lyle along the Columbia Hills as far as Stacker Mountain, the gentler south limb has more springs and greater effluence of high-perched ground water than the forested, more steeply dipping north limb. On the southwardsloping basalt surface near the crest of Columbia Hills, each square mile has an average of about one spring, and the flows range from 2 to $10 \mathrm{gpm}$. This discharge from the high-perched ground water is the equivalent of about a quarter of an inch of precipitation per year per square mile over the possible infiltration area of basalt terrain.

The more shattered and disjointed basalt at shallow depth and its colluvial cover beneath the north slope permit water to infiltrate and move at depth to the north. The flow of small springs from high-perched water is limited mainly to seepage areas below snowdrift sites. Most of the infiltrated water does not re- 
appear. The water that percolates deeply probably reaches the main water table and discharges directly to the river channels. Much of the infiltrated water must bo caught in the deep soil zone from which it is transpired by the forest trees and by brush and other vegetation, which is more abundant on the northern side of the ridge.

South and east of Stacker Mountain, the more symmetrical structure of the Columbia Hills anticline causes about equal distribution of small springs on the two flanks.

Locally, individual structural features cause particular ground-water outflows to the Columbia Hills upland. Examples include (1) the spring flow of $30 \mathrm{gpm}$ at a change in the plunge of a shallow secondary syncline 2 miles northwest of Wishram (NW1/4 NE1/4 sec. 12, T. 2 N., R. 14 E.) and (2) the spring flow of $30 \mathrm{gpm}$ emerging above brecciated and overturned basalt at the point of the north-south anticlinal segment in NW1/4 NE $1 / 4$ sec. 9, T. 2 N., R. 14 E. The springs that flow from each side of Haystack Butte just below the southern brow of the ridge (pl. 1) seem to be a special case. Lateral dips on the top part of the basalt, possibly due to bulging upward of the basalt around the young volcanic conduit, may cause the discharge at these springs of part of the water which infiltrates to the permeable young volcanic materials making up the butte.

From the Warwick fault eastward to the Davies Pass syncline, the Columbia Hills anticline is asymmetrical, the south limb being the steeper. (See section $B-B^{\prime}, \mathrm{pl}$. 1.) The same relation of spring flows to gentler slopes, as observed farther west, occurs here; the gentle north slope has more springs discharging from the perched ground-water bodies, even though that slope is but slightly cut by ravines. The springs on the south side are limited to weak discharges high up near the rim and at intermediate levels on the rock benches.

Swale Creek valley is bounded by a 400 -foot-high anticlinal arch which trends generally east-west about a mile north of the mapped area. Between this low arch and the Columbia Hills anticline, the intervening Swale Creek syncline plunges gently west to the head of Swale Canyon, near which it ends. The Warwick fault crosses this downwarp and should form a tectonic closure of the upper part of Swale Creek valley, locally called the "Centerville Valley." The ground-water conditions in this closed part of the synclinal structure are untested, but an impoundment is believed to be present. A few shallow wells with water levels close to the surface indicate that the ground water in the top part of the basalt is held to an altitude of at least 1,560 feet at Warwick. The fault barrier may block the ground water suffi- ciently that water under artesian pressure is present in the basalt to the east. (See fig. 18.)

No wells more than 110 feet deep are known to have tested the ground-water conditions in the basalt between Centerville and Warwick. Several wells southwest of Centerville obtain water in gravel (?) or rubbly basalt (?) at depths of less than a hundred feet and yield sufficient water for some irrigation. The water levels in those wells stand near an altitude of 1,580 feet. The Woods well (3N/15-21A1) yields $125 \mathrm{gpm}$ from "gravel" and has some artesian flow, though it is only 70 feet deep. An 80-foot domestic well (25C1) in the basalt at Warwick has a water level 10 feet below the surface - at an altitude of about 1,555 feet. This altitude is equivalent to that of the creek in the rock channel nearby. Water flows at the rate of about $100 \mathrm{gpm}$ from springs in the creekbed along the Warwick fault; such leakage may be a principal direct overflow at the fault zone closing this structural basin. Seepage that wets the soils to the surface is common in the lowest part of the valley above Warwick and may represent discharge of ground water.

The boundary most likely to allow lateral escape of ground water from upper Swale Creek valley appears to be the low anticline on the north. The land surface along this gentle arch is at a general altitude of 2,000 feet and approximately on the top of the basalt. In this anticlinal arch, the basalt layers are about 400 feet above the altitude of the corresponding layers along the axis of the Swale Creek syncline. For each successively deeper permeable layer, the anticlinal arch provides a correspondingly lower spillway altitude (fig. 18). Thus, hypothetically, the spill level of ground water at 400 feet depth on the anticlinal axis could balance a groundwater level equal to the top of the basalt at Warwick.

Several preliminary generalizations may be made about the geologically closed ground-water basin:

1. The ground water in the upper part of the basalt probably is perched above the main water table.

2. Static water levels may be successively lower as succeeding layers are penetrated, and the ground water below a depth of about 400 feet may have natural levels below that of the creek.

3. Any flowing artesian water will occur near, and east of, Warwick and in the upper 400 feet of the basalt, though water which rises to an altitude of 1,560 1,580 feet may occur in the basalt beneath several square miles of valley plain east of Warwick.

4. If highly permeable layers occur in the top 400 feet, the ground water beneath this part of the basin could store an annual increment of at least a few hundred acre-feet of water. 


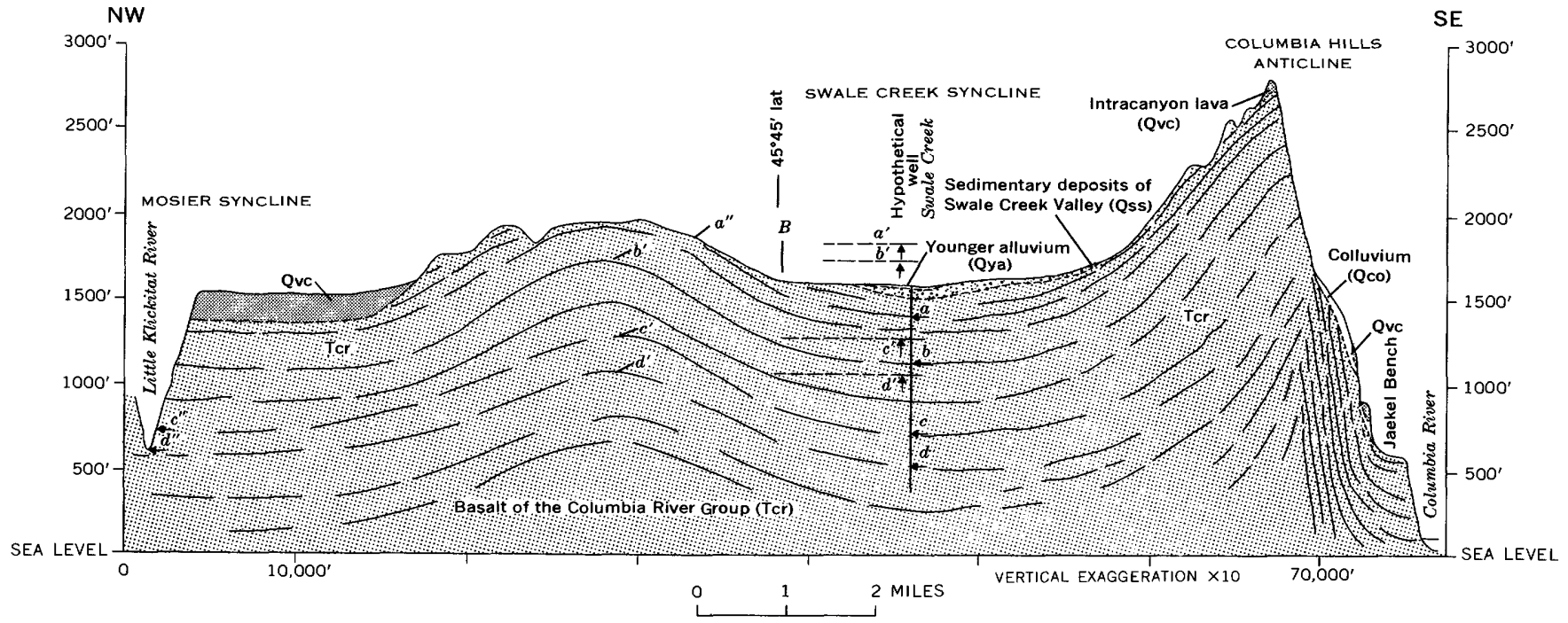

Figure 18.- Section across Swale Creek valley along the northern part, and northward extension, of section $B-B^{\prime}$ (pl. 1). The water levels and points of passage over the crest of the lateral anticline $\left(b^{\prime}, c^{\prime}, d^{\prime}\right)$ for the ground water confined in postulated aquifers (a, b, c, d) are indicated for a hypothetical well, and the assumed drainage points $\left(c^{\prime \prime}, d^{\prime \prime}\right)$ are shown for aquifers $c$ and $d$.

5. Some of the ground water that now percolates to the canyon of the Little Klickitat River and is "wasted" might be withdrawn by future wells from this structural reservoir and be saved.

6. Presumably, future well developments will demonstrate that withdrawals of ground water from storage will make room for recharge by infiltration of surface runoff during the winter and spring months, when such a decrease in the runoff from Swale Creek basin will be beneficial.

Three miles west of Warwick, the Swale Creek valley ends abruptly where the deep Swale Canyon has been entrenched headward as far as sec. 28. Between Warwick and the canyon, stronger alluviation from the south has kept the creek pushed north of the synclinal axis, which follows the central part of the valley. Thus, near the head of Swale Canyon, the creek is cut into basalt of a prevailing southeasterly dip. The downdrop of the western side of the Warwick fault has given the basalt beneath the lower Swale Creek valley a slight dip eastward toward the fault. Ground water with levels near the surface is shown in two shallow basalt wells in the westcentral part of sec. 25 and indicates that this southeastward dip impounds some perched ground water beneath the southeast part of the valley plains in the lower part of Swale Creek valley.

\section{SUMMARY}

Tectonic deformation affects ground water chiefly in the following ways:

1. Increases the opportunity for infiltration and downward transfer of water by bringing parts of aqui- fers to, or close to, the surface and by providing steeply inclined zones of broken rock.

2. Tilts the tabular permeable layers so that advantageous gradients are available for lateral movement in the basalt.

3. Causes ground water to be impounded because of the downwarped basinal structures or because of the destruction of lateral permeability at fault zones. Some of these impoundments afford water storage at high levels beneath parts of upland plateaus, where no other significant source of water occurs naturally during the dry season.

4. Partly determines the pattern and lateral shape of stream valleys (particularly valleys that were consequent upon the terrain underlain by folded formations). It helps to determine the rates of flow in streams by directing runoff down dip slopes, diverting water to transverse drainages, raising the different rocks to where they can be entrenched by streams, and making some rocks more susceptible to erosion.

5. Alters the quality of ground water in places by increasing the opportunity for vertical circulation through rocks of different temperature or of different chemical character.

The structural study of the ground-water situations in the basalt of this area has shown a general shedding of the ground-water runoff (as well as the surface runoff) away from the anticlines and an accumulation of that ground water in the synclines (pl. 1). Within this broad structural control, further structural effect on the ground water in the basalt is shown by such unusual sit- 
uations as (1) the 400-foot elevation of the water levels behind the tightly folded Rocky Prairie anticline, (2) the 600-foot elevation of the ground water behind a fault barrier beneath Mill Creek valley, (3) the isolation of the ground water in "The Dalles Ground Water Reservoir" by several faults and folds, (4) the 800 - to 1,300 foot elevation of the ground water behind the gently arched Lash Ranch anticline and associated faults, and (5) the 1,500-foot elevation of ground water beneath the Swale Creek basin by enclosing anticlines and a transverse fault.

Structural controls and the corresponding groundwater phenomena are so conclusively cause-and-effect in this area, even though lack of data leaves some phenomena unexplained, that a good interpretation of geologic structure is shown to be imperative to the prediction of ground-water conditions in the basalt.

\section{REFERENCES CITED}

Allison, I. C., 1933, New version of the Spokane flood: Geol. Soc. America Bull., v. 44, p. 675-722.

Bretz, J. H., 1924, The Dalles type of river channel : Jour. Geology, v. 32, p. 139-149, 8 figs.

Buwalda, J. P., 1929, A Neocene erosion surface in central Oregon: Carnegie Inst. Washington Pub. 404, p. 1-10, 1 pl.

Buwalda, J. P., and Moore, B. N., 1930, The Dalles and Hood River Formations and the Columbia River Gorge: Carnegie Inst. Washington Pub. 404, p. 11-26, 1 fig.

Callaghan Eugene, and Buddington, A. F., 1938, Metalliferous mineral deposits of the Cascade Range in Oregon: U.S. Geol. Survey Bull. 893, 141 p., 22 pls., 7 figs.

Campbell, C. D., 1950, Petrology of the Columbia River Basalts ; present status and ideas for future work: Northwest Sci., v. 24, p. 74-83.

Chaney, R. W., 1944, The Dalles flora [Oregon], chap. 11 of Chaney, R. W., ed., Pliocene floras of California and Oregon: Carnegie Inst. Washington Pub. 553, Contr. Paleontology, p. 1-19, 353-373, illus. incl. index map.

Donath, F. A., and Parker, R. B., 1964, Folds and folding; Geol. Soc. America Bull., v. 75, p. 45-62, 8 pls., 10 figs.

Fenneman, N. M., 1931, Physiography of Western United States : New York, McGraw-Hill Book Co., 534 p., 173 figs.

Flint, R. F., 1937, Pleistocene drift border in eastern Washington: Geol. Soc. America Bull., v. 48, no. 2, p. 203-232.

Foxworthy, B. L., and Bryant, C. T., 1967, Artificial recharge through a well tapping basalt aquifers at The Dalles, Oregon: U.S. Geol. Survey Water-Supply Paper 1594-E, 55 p., 1 pl., 7 figs.
Hodge, E. T., 1932, Geological map of north-central Oregon: Oregon Univ. Pubs. Geology, v. 1, no. 5.

- 1942, Geology of north-central Oregon: Oregon State College Studies in Geology 3, 76. p., 23 figs., map.

Hogenson, G. M., 1964, Geology and ground water of the Umatilla River basin, Oregon: U.S. Geol. Survey Water-Supply Paper 1620, 162 p., 2 pls., 14 figs.

Mayers, L. R., 1964, Soil survey of Sherman County, Oregon: U.S. Dept. Agriculture and Oregon Agr. Expt. Sta., ser. 1959, no. 37, 105 p., 18 tables, 27 figs., 2 maps, 80 photog. maps.

Newcomb, R. C. 1959, Some preliminary notes on ground water in the Columbia River Basalt: Northwest Sci., v. 33, no. 1, p. 1-18.

1963, Ground water in the Orchard syncline, Wasco County, Oregon: Oregon Dept. Geology and Mineral Industries, The Ore Bin, v. 25, no. 8, p. 133-138.

- 1965, Ground water of the Walla Walla River basin, Washington-Oregon: Washington Div. Water Resources Bull. 21, 151 p., 3 pls., 15 figs.

- 1966, Lithology and eastward extension of the Dalles Formation, Oregon and Washington, in Geological Survey Research 1966 : U.S. Geol. Survey Prof. Paper 550-D, p. D59D63, 1 fig.

- 1967, The Dalles-Umatilla syncline, Oregon and Washington, in Geological Survey Research 1967 : U.S. Geol. Survey Prof. Paper 575-B, p. B88-B93, 3 figs.

Nichols, R. L., 1936, Flow units in basalt: Jour. Geology, v. 44, p. 617-630.

Piper, A. M., 1932, Geology and ground-water resources of The Dalles region, Oregon: U.S. Geol. Survey Water-Supply Paper 659-B, p. 107-189, 9 pls., 3 figs.

Russell, I. C., 1893, A geological reconnaissance in central Washington : U.S. Geol. Survey Bull. 108, 93 p., 12 pls.

Sargent, S. C., 1956, Pl. 1 in Foundation report of the Dalles Dam, The Dalles, Oregon: U.S. Army, Corps of Engineers, Portland, Oreg., Dist.

Stanleý, Lewis A., 1959, Determination of a critical ground-water area in The Dalles area, Oregon: Adm. order of the State Engineer, Dec. 11, 1959.

Trimble, D. E., 1950, Joint controlled channeling in the Columbia River Basalt : Northwest Sci., v. 24, p. 84-88.

Walters, K. L., and Grolier, M. J., 1960, Geology and ground water resources of the Columbia Basin Project area, Washington: Washington Div. Water Resources Water Supply Bull. 8, v. 1, 518 p., 3 pls., 25 figs.

Williams, I. A., 1916, The Columbia River Gorge, its geologic history interpreted from the Columbia River Highway: Oregon Bur. Mines and Geology, v. 2, no. 3, 130 p., 77 illus. 


$$
\text { - }
$$


. 